\title{
Kill your darlings?
}

\section{Do new aid flows help achieve a poverty minimizing allocation of aid}

\author{
Sven Tengstam and Ann-Sofie Isaksson
}

\begin{abstract}
In this study, we derive a poverty-minimizing allocation rule, based on which we assess the povertyefficiency of actual aid allocations, with a special focus on the comparative impact of new donors and new non-aid flows. The results suggest a substantial misallocation of aid. Our benchmark estimates indicate that donors should reallocate nearly half the total aid budget from aid darlings (countries receiving more aid than the allocation rule specifies) to aid orphans (countries receiving less aid than the allocation rule specifies). The estimated poverty-reducing efficiency varies considerably across donors. Whereas new global actors such as the Gates foundation perform well above average, the non-DAC bilateral donors perform clearly worse. Overall, neither the new donors nor the new financial flows alleviate the observed misallocation of aid. While the new donors stand for a non-negligible share of overall poverty reduction, together they perform below average in terms of poverty reduction per aid dollar. Similarly, rather than counteracting the relative neglect of countries identified as particularly underfunded in terms of aid, the non-aid financial flows add to the inequitable distribution. Based on an extensive battery of alternative model calibrations, we establish upper and lower bounds on our estimates, allowing for clear policy recommendations.
\end{abstract}

JEL classification: D63; E61; F35; O11

Keywords: Aid allocation; Poverty; Donors; Official development assistance; Other official flows

\section{Introduction}

Among official donor objectives, poverty reduction takes center stage. In 2015, world leaders adopted the 2030 Agenda for Sustainable Development. On top of its list of goals is the objective to 'end poverty in all its forms everywhere' (United Nations, 2019b). No less grand is the World Bank's mission, carved in stone at their Washington headquarters: 'Our Dream is a World Free of Poverty' (World Bank, 2019). While priorities vary across bilateral donors, the overarching objective of the Organization for Economic Co-operation and Development's (OECD) Development Assistance Committee (DAC), consisting of 30 influential donors, is to contribute to the implementation of the 2030 Agenda and thus its goal to end poverty. Yet, despite being roughly ten times richer in per capita terms, Tunisia receives nearly five times as much foreign aid per person than the Democratic Republic of Congo (DRC). 
This is not necessarily surprising. The allocation of aid among countries clearly reflects multiple objectives, some legitimate, others arguably less so. Aid may be used to rebuild postconflict societies and to meet humanitarian emergencies, or for that matter, to reward allies, punish enemies, build coalitions and more generally support the strategic or commercial interests of the donor (Collier and Dollar, 2002; Dreher et al., 2018). Indeed, ample evidence from the last couple of decades suggests that when allocating aid across countries, donors tend to be motivated as much by political strategy and economic interests, as by the needs and policy performance of the recipient countries (e.g. Alesina and Dollar, 2000; Alesina and Weder, 2002; Dollar and Levin, 2006; Kuziemko and Werker, 2006; Hoeffler and Outram, 2011; Dreher et al., 2018.) Justifiable or not, this allocation pattern goes against the official donor emphasis on poverty reduction.

At the same time, however, the aid landscape has changed dramatically over the period: new sources of development finance have emerged and the development cooperation arena has seen continued diversification of actors, instruments and delivery mechanisms (Kharas and Rogerson, 2012; Mawdsley et al, 2014). The role of traditional official development assistance (ODA) in development cooperation is becoming less dominant (OECD, 2014). In parallel, the dominance of aid from the OECD-DAC countries is declining, with recent years seeing a sharp increase in development finance from non-Western donors, with China at the forefront (see e.g. Strange et al., 2015; Dreher et al., 2011; Dreher et al., 2015). The changing circumstances call for a renewed focus on the implications and challenges of development cooperation in general, and for an understanding of the implications of the rise of new actors and financial flows in particular.

The aim of this paper is to derive a poverty-minimizing - or poverty-efficient - allocation of aid and, based on this, assess the poverty-efficiency of actual aid allocations, with a special focus on the comparative impact of new donors and new (non-aid) financial flows on the most under-funded countries. We first look at aggregate flows, and ask how much poverty could be reduced if aid was allocated according to the specified rule. Next, we break down the analysis by donor groups and flow types and assess the poverty-efficiency of the respective allocations. On the recipient side, we identify winners and losers - aid darlings and aid orphans - and assess to what extent new donors and new financial flows (NFFs) contribute to a more or less povertyefficient allocation.

The results suggest a substantial misallocation of aid. Our benchmark estimates indicate that donors should reallocate nearly half the total aid budget from darling to orphan countries. The estimated poverty-reducing efficiency varies considerably across donors. In terms of 
average poverty reduction per aid dollar, new global actors such as the Gates foundation perform well above average and the non-DAC bilateral donors clearly below. Overall, neither the new donors nor the new financial flows alleviate the observed misallocation of aid. While the new donors stand for a non-negligible share of overall poverty reduction, together they perform below average in terms of poverty reduction per aid dollar. Similarly, rather than counteracting the relative neglect of the particularly underfunded countries in the allocation of aid, the non-aid financial flows add to the inequitable distribution. For the countries that we identify as aid orphans, these flows are not significant enough to substitute for the lack of aid.

Previous studies in this vein, e.g. the seminal work of Collier and Dollar (2001 and 2002), demonstrate that the actual allocation of aid is radically different from the poverty-efficient allocation, and thus that reallocating aid can come with significant improvements in terms of poverty reduction. Our contribution to this literature is twofold.

First, given the changing aid landscape, we incorporate new donors and new (non-aid) financial flows into the poverty minimizing aid allocation literature, investigating explicitly how these donors and flows matter for the poor underfunded countries. NFF is clearly a very heterogeneous category including flows that take place for widely different reasons. As such, NFFs are not directly comparable to aid, and we thus cannot apply the same analytical framework as that used to assess the poverty reducing efficiency of aid (see Section 2 and 3). Nonetheless, it is interesting to explore the distributional profiles of the new financial flows, and in particular, whether they help counteract the observed misallocation of aid.

We thus base our estimations on a more comprehensive dataset than previous studies. In particular, we compile aid data for a large group of new donors and on alternative sources of development finance. On top of the traditional multilateral and DAC bilateral donors, we incorporate a wide range of non-DAC bilateral donors, ${ }^{1}$ as well as a group of donors that are DAC members today, but were not for most of the period we study (2009-2013). ${ }^{2}$ Moreover, we include data on a wide range of non-aid NFFs, namely 'Other Official Flows', Personal remittances, FDI, as well as on aid from International NGOs and new global actors. ${ }^{3}$

Second, acknowledging that optimal aid allocation estimations are sensitive to model calibrations and different measures of need, we thoroughly investigate how robust our

\footnotetext{
${ }^{1}$ Brazil, Bulgaria, Chile, China, Colombia, Croatia, Estonia, India, Israel, Kazakhstan, Kuwait, Latvia, Liechtenstein, Lithuania, Monaco, Qatar, Russia, Saudi Arabia, South Africa, Taiwan, Thailand, Turkey and the United Arab Emirates.

${ }^{2}$ The Czech Republic, Hungary, Iceland, Poland, the Slovak Republic and Slovenia.

${ }^{3}$ The following new global actors are included: The Bill and Melinda Gates Fund (BMGF), The Global Fund to Fight AIDS, Tuberculosis and Malaria (GFATM), the Global Alliance for Vaccines and Immunization (GAVI), and the Global Environment Facility (GEF).
} 
benchmark results are to alternative calibrations and measures. Based on this, we establish upper and lower bounds on our estimates, allowing for more solid policy recommendations.

\section{Optimal aid allocation}

In their simplest form, optimal aid allocation rules tend to consider two characteristics of recipient countries: their need for aid and their ability to use it (Carter, 2014). The literature has to a large extent been built around the pioneering work of Collier and Dollar $(2001,2002)$, who in line with this, argue that aid should be allocated to countries that are poor and wellgoverned. They propose that aid should be distributed so as to maximize poverty reduction, via growth. Based on a growth regression (in turn based on Burnside and Dollar, 2000), they estimate that aid is more efficient at reducing poverty when government effectiveness is higher. Hence, according to their logic, holding the level of poverty constant, aid should increase with policy, and holding policy constant, it should increase with poverty.

The idea that the effect of aid is conditional on the institutional/political framework in the recipient country (Burnside and Dollar, 2000; Collier and Dollar, 2001, 2002) has been influential in donor circles. Notably, however, comparatively little weight is given to poverty. Consider the 'Performance Based Allocation' (PBA) rule used by the World Bank (and other multilateral development banks) to allocate its concessional International Development Association (IDA) funds. Funds are allocated based on performance (CPR) and income (GNI) per capita:

$$
\text { IDA country allocation }=C P R^{3} * \text { GNI per capita }{ }^{-0.125} * \text { population }
$$

$\mathrm{CPR}$ is a country performance rating focusing on macroeconomic management, structural policies, social policies, public sector management and institutions, and the quality of management of IDA's projects and programs. ${ }^{4}$ Need is taken into account via the fact that IDA is only given to countries with a GNI/cap below a certain threshold. But apart from that, overwhelming weight is given to performance, or the institutional/policy environment of the recipient country. While the weight given to CPR has in fact been reduced (the exponent has

\footnotetext{
${ }^{4}$ Specifically, the CPR is calculated as follows: $C P R=0.24 C P I A_{A}$ to $C+0.68 C P I A_{D}+0.08 P P R$, where the country policy and institutional assessment (CPIA) index is based on indicators focusing on (A) macroeconomic management, (B) structural policies, (C) social policies, and (D) public sector management and institutions, and PPR is the IDA portfolio performance rating. As one can see, the cluster focusing on institutions and public sector management is given the highest weight.
} 
been lowered in steps from 5 to 3 ) over the last couple of years in order to increase the povertyorientation of the formula (IDA, 2016), the rule is still very much performance focused.

While very influential, the optimal aid allocation rule of Collier and Dollar (2001, 2002) has been criticized on several grounds (for an overview, see Sterck et al., 2017). Below we discuss proposed developments that we seek to incorporate in our allocation formula.

\subsection{An uncomfortable trade-off between need and effectiveness}

First, the objective function of Collier and Dollar $(2001,2002)$ can, just as the PBA rule of the World Bank, be criticized on fairness grounds. As noted by McGillivray and Pham (2017, p. 1) it contains an "uncomfortable trade-off between need and effectiveness". The poorest countries often have the lowest levels of performance and are thus allocated less aid.

To begin with, one could question the overwhelming weight given to performance, or policy/institutional environment, in the PBA rule. In the aid effectiveness literature, the leading proponents of the view that the impact of aid is conditional on policy are Burnside and Dollar, who in an often-cited study from the turn of the millennium (Burnside and Dollar, 2000) found that aid has a positive effect on growth only in countries with sound fiscal, monetary and trade policies. As noted, Collier and Dollar's allocation rule $(2001,2002)$ is based on this estimation. The Burnside and Dollar results were later called into question, however, and have been found to be sensitive to specification and sample (Hansen and Tarp, 2001; Easterly, 2003; Easterly et al., 2004; Dalgaard et al.; 2004; Roodman, 2007). In more recent accounts, the consensus is rather that the aggregate aid-growth literature offers no empirical evidence of aid effectiveness being conditional on policy (Arndt et al., 2010; Clemens et al., 2012; Bourguignon and Gunning, 2016; Guillaumont, et al., 2017; Mekasha and Tarp, 2019).

A lack of aggregate evidence of aid effectiveness being conditional on policy should of course not be interpreted as the recipient country policy environment being irrelevant; few researchers and practitioners would dispute the merits of a sound policy environment. That said, though, an aid allocation rule placing a significantly higher weight on the policy dimension compared to the need dimension can hardly be motivated with reference to the empirical literature on the relationship between aid and growth.

Furthermore, one can argue that poor countries should not receive less aid due to structural handicaps beyond their control. Llavador and Roemer (2001) propose an equality of opportunity approach to aid allocation, arguing that poor countries should not to be penalized for a growth-adverse environment for which they cannot be deemed responsible. According to 
this line of thinking, aid should compensate countries for inherited disadvantages while allowing effort to produce differential rewards. Cogneau and Naudet (2007) also adopt an equal opportunities approach, but argue that aid should focus on equalizing future poverty risks across developing countries. Similarly, Wood (2008, p. 1135) argues that, "donors and people care - for intellectually and morally defensible reasons - about both current and future levels of poverty", and therefore propose to minimize the discounted sum of future poverty, rather than, as Collier and Dollar, current poverty.

Relatedly, but focusing on how these ideas have been put to use among donors in practice, Guillaumont et al. $(2017 \mathrm{a}, \mathrm{b})$ argue that the performance based allocation rule of the World Bank fails to take account of key structural handicaps to development facing countries independent of present political will and efforts. In its current form, the PBA rule does not allow countries performing badly due to e.g. conflict or natural disasters to receive a level of aid in accordance with their needs. Rather, considering that 'performance', as measured in the PBA, is likely to be pro-cyclical, the impact of a negative exogenous shock will according to this allocation rule be magnified by lower aid. Instead of incorporating vulnerability into their allocation formula, the World Bank currently makes exceptions to the PBA rule, offering special treatment to different categories of fragile states. Similarly, Guillaumont and co-authors argue that low levels of human capital is a structural handicap that a country should not be penalized for. Despite the best of intentions and significant efforts, countries with low levels of human capital are likely to score poorly on the PBA.

On top of fairness considerations, an allocation rule that better captures the vulnerability of recipient countries can be justified with reference to efficiency. Exogenous sources of instability, and the growth volatility they induce, lowers average growth and is harmful to poor and vulnerable groups (Guillaumont and Wagner, 2013). The stabilizing impact of aid - i.e. that it dampens the negative impact of exogenous shocks on growth and development - should increase growth as well as make it more pro-poor (Guillaumont et al. (2017a,b). Similarly, not penalizing countries with low levels of human capital can be motivated in terms of efficiency. Aid tends to have a knowledge content and is often targeted at human capital development, and it is reasonable to argue that the marginal impact of aid on growth via human capital will be higher when the initial level of human capital is lower.

The implication of these arguments is, according to Guillaumont et al. (2017a), that the marginal poverty reduction per aid dollar is higher in countries with high vulnerability and low human capital. For this reason, they propose the use of an 'augmented PBA' where the measurement of performance by policy indicators is adjusted for the impact of structural 
handicaps, namely vulnerability and low human capital. Specifically, they propose an 'Augmented Country Policy Rating' (ACPR) that is a weighted average of the original CPR and the Economic Vulnerability Index (EVI) and Human Assets Index (HAI) used by the UN to identify LDCs. EVI is a composite index capturing the exposure to natural or external exogenous chocks. HAI is a composite index of health and educational components. The higher ACPR, the higher is the presumed aid effectiveness. Therefore, in an optimal aid allocation, countries with high poverty and high ACPR should be favored.

To integrate structural economic vulnerability and low human capital into the allocation formula we will follow Guillaumont et al. (2017a) and use the ACPR as policy measure in our benchmark calibration, but will also evaluate how sensitive the results are to using CPR instead of ACPR.

\subsection{Focusing on growth or consumption}

Another concern has to do with the focus on growth. As noted, Collier and Dollar $(2001,2002)$ use an estimated empirical relationship between aid and growth to derive an allocation rule that maximizes poverty reduction via growth. This can be questioned on both theoretical and empirical grounds.

Arguing that aid can only reduce poverty by increasing growth has been criticized for being 'reductionist' and not 'sufficiently nuanced' (McGillivray and Pham, 2017). In particular, giving no weight to aid-funded consumption and investment is arguably problematic considering that most aid does not have growth as its main purpose, but rather private and public consumption and investment intended to be welfare enhancing in itself.

An alternative is to derive an allocation that seeks to maximize recipient welfare rather than growth (Carter, 2014). In line with Bourguignon and Platteau (2017), one can focus on aid-consumption, i.e. the effect aid has directly on consumption, instead of aid-growthconsumption, i.e. the effect aid has on growth, and the effect aid has on consumption via growth.

Empirically, there are also reasons to focus on consumption rather than growth. While the aggregate effect of aid on growth is difficult to measure, yielding fragile estimates (see Clemens et al. 2012); it is easier to show that aid increases consumption and welfare 'there and then on the ground' (the so called micro-macro paradox). This is not to say that there is no effect of aid on economic growth. Even though endogeneity concerns and low statistical power make it difficult to get reliable estimates, the most ambitious attempts (see Clemens et al. 2012) 
suggests that there is indeed a positive impact. Nevertheless, considering a more direct effect of aid rather than its effect via growth appears warranted.

As it turns out, the Collier and Dollar (2002) model is easily extended to allow aid to have a direct effect on income. Doing so, we assume that an increase in national income resulting from an inflow of aid trickles down to the poor in the same way as would an increase in national income instead resulting from growth, which appears reasonable.

\subsection{Diminishing returns to aid}

Assuming that aid has diminishing returns is standard in the optimal aid allocation literature. The argument is that recipient countries, due to e.g. institutional constraints, have limited absorptive capacity, i.e. ability to absorb and use aid in a way that achieves a given objective. With large aid volumes, a recipient country will thus reach a point where they can no longer absorb or spend aid efficiently.

The existence of diminishing returns is a robust finding in the aid-growth literature (see e.g. Burnside and Dollar, 2000; Hansen and Tarp, 2001; Dalgaard et al., 2004; Easterly et al., 2004; Clemens et al 2012). Specifically, these results indicate that aid is positively related to growth up to a certain level of aid relative to recipient GDP - often referred to as the saturation point - and even negatively related thereafter. Considering the robustness of this finding, the question is not so much whether to assume diminishing returns, but rather to specify the saturation point. Below we develop our theoretical framework, discussing theoretical assumptions like this one.

\section{Theoretical framework}

In this section, we derive a poverty minimizing allocation of aid. Our model builds on the pioneering work of Collier and Dollar (2001, 2002), but incorporates a number of developments discussed in Section 2. In particular, rather than deriving an allocation rule that maximizes poverty reduction via growth, we allow aid to have a direct effect on income, while taking into account that aid has diminishing returns in terms of poverty reduction. ${ }^{5}$ Having

\footnotetext{
${ }^{5}$ Worth emphasizing, the below framework applies to aid rather than new financial flows. We return to the NFFs in the results section, where we assess to what extent non-aid flows help counteract the observed misallocation of aid.
} 
derived a poverty minimizing allocation of aid, we are able to compare actual aid levels to optimal aid levels among aid receiving countries. Hence, in a next step, we assess the poverty reduction that donors could hypothetically achieve by reallocating aid from darling countries (that have received more aid than our allocation rule recommends) to orphan countries (that have received less aid than our allocation rule recommends). Finally, we break down the analysis by donors / donor groups and assess their comparative poverty reducing efficiency.

\subsection{Deriving the poverty minimizing allocation of aid}

Collier and Dollar (2002) formulate a model assuming that the objective function of donors is to allocate aid among countries so as to

$$
\begin{array}{ll}
\text { Max poverty reduction } & \sum_{i} G_{i} \alpha_{i} h_{i}^{0} N_{i} \\
\text { subject to } & \sum_{i} A_{i} y_{i} N_{i}=a_{t o t}, \quad A_{i} \geq 0
\end{array}
$$

where $y_{i}$ is GDP per capita in in country $i, A_{i}$ is aid/GDP, $N_{i}$ is population, $G_{i}$ is the growth rate of per capita income, $h_{i}^{0}$ is a measure of initial (before aid) poverty, and $\alpha_{i}$ is the (negative) elasticity of poverty with respect to income. The total amount of aid is denoted $a_{t o t}$.

As discussed in Section 2, deriving an aid allocation rule that maximizes poverty reduction via growth can be questioned on both theoretical and empirical grounds. As also noted, however, one can easily extend the Collier and Dollar (2002) setup to allow aid to have a direct effect on national income. Recall that $\alpha_{i}$ is the income elasticity of poverty. Income, in this context, can refer to any income. An increase in national income has an effect on poverty, no matter if this change in income is due to growth, or to an inflow of aid.

Against this background, we now depart from the Collier and Dollar setup. In particular, instead of letting aid affect poverty only via growth, we formulate a model considering the direct effect of aid on income (which allows public and private consumption) and thereby on poverty. From an accounting perspective, the effect of aid on income is straightforward. Aid simply constitutes an inflow of resources that adds to the recipient country's pre-aid-income. We slightly modify this perspective and consider 'realized income', taking into account that aid has diminishing returns. One way to put this is that an increasing fraction of the aid received is lost due to transaction costs. The aid that remains, net of transaction costs, adds to the recipient country's pre-aid-income, and forms realized income. Just as the standard assumption 
of diminishing returns in the aid-growth literature, we thus assume a quadratic relationship between aid and realized income, i.e. that recipient country governments have limited absorptive capacity when it comes to delivering consumption (realized per capita income), just as in delivering economic growth.

Hence, with large aid volumes, a recipient country will reach a point where they can no longer absorb or spend aid efficiently. Indeed, after this point aid even has a negative effect. Denoting this saturation point $\beta_{i}$, and the fraction of the first aid-dollar that is not lost due to transaction costs $\varepsilon_{i}$, realized per capita income, denoted $x_{i}$, is given by:

$$
x_{i}=y_{i} q_{i}
$$

Where $q_{i}$ is the factor for the aid - realized per capita income relationship:

$$
q_{i}=1+\varepsilon_{i}\left(A_{i}-\frac{A_{i}{ }^{2}}{2 \beta_{i}}\right)
$$

Like Collier and Dollar, we let $\varepsilon_{i}$ and $\beta_{i}$ vary with policy. For a more detailed discussion of the functional form and calibration of $\varepsilon_{i}$ and $\beta_{i}$, see Appendix B. Under ideal policy conditions, $\varepsilon_{i}$ would equal one, implying that none of the first aid-dollar is lost due to transaction costs. In our benchmark calibration, we assume that the saturation point for a country with average policy score, denoted $\beta_{0}$, occurs when aid constitutes 25 percent of GDP. We base this figure on the estimates in Clemens et al (2012), who find inflection points for the aid-growth relationship when aid exceeds about 20-25 percent of GDP (which we adjust for differences in aid flow coverage and for our use of commitments rather than disbursements). As such, we assume that the saturation point for consumption-aid is the same as for growth-aid. We are not aware of any equivalent estimates for consumption-aid, and it is arguably reasonable that the amount of aid a recipient country can handle gives a similar pattern of diminishing returns for different economic outcomes. In the robustness analysis, we explore the sensitivity of results to using alternative saturation points.

Poverty (post aid), denoted $h_{i}$, is a function of realized per capita income, assuming a constant realized per capita income elasticity of poverty:

$$
h_{i}=h_{i}^{0}\left(\frac{x_{i}}{y_{i}}\right)^{-\alpha_{i}}
$$

Furthermore, we assume that $\alpha_{i}=\alpha$, i.e., that the elasticity of poverty with respect to realized per capita income is the same in all countries. Since the empirical estimates of elasticities tend to vary considerably based on the poverty measure used (e.g. based on the specific poverty line chosen and whether using a headcount measure or and indicator capturing 
the depth of poverty), we argue that it is more transparent to use the same elasticity across the board. Based on previous empirical studies (e.g. Bourguignon, 2000; Collier and Dollar, 2002; Bigsten and Shimeles, 2007) we use $\alpha=1.5$ in the benchmark calibration, but explore the sensitivity of results to using alternative elasticities $(\alpha=1$ and $\alpha=2){ }^{6}$

Equations (2) - (4) allow us to write the poverty function of country $i$ as:

$$
h_{i}=h_{i}^{0}\left(1+\varepsilon_{i}\left(A_{i}-\frac{A_{i}^{2}}{2 \beta_{i}}\right)\right)^{-\alpha}
$$

We frame the optimization problem as one of minimizing poverty rather than, as Collier and Dollar (2012), of maximizing poverty reduction. Hence, the objective function for donors is to allocate aid among countries so as to:

Min total poverty $\sum_{i} h_{i} N_{i}$

$$
\text { subject to } \quad \sum_{i} A_{i} y_{i} N_{i}=a_{\text {tot }}, \quad A_{i} \geq 0
$$

Our formulation takes into account that aid has diminishing returns on poverty not only through the quadratic relationship between aid and national income, but also through the poverty function being a decreasing but convex function of national income (taking into account the aid portion of national income). This contrasts with the set up used in Collier and Dollar (2002), and in most of this literature, where the convexity of the poverty function is ignored, and poverty reduction achieved from growth in country $i$ is assumed to be given by $G_{i} \alpha h_{i}^{0} N_{i}$. With low levels of growth, this is a fairly accurate approximation of the correct expression $\left(1-\frac{1}{\left(1+G_{i}\right)^{\alpha}}\right) h_{i}^{0} N_{i}$, assuming that the elasticity is constant. Using this approximation, one can solve the first order conditions algebraically and thus derive an explicit expression for the solution. The higher the growth level, however, the more imprecise this approximation becomes. ${ }^{7}$ By framing the optimization problem as one of minimizing poverty rather than maximizing poverty reduction, we avoid the above approximation, and thereby take the convexity of the poverty function into account and obtain more precise estimates. Without the approximation, however, there exists no algebraic solution to the first order conditions, and we must rely on numerical solutions. To our knowledge, this is the first aid effectiveness model to

\footnotetext{
${ }^{6}$ For a more detailed discussion of $\alpha$, see Appendix B.

${ }^{7}$ Consider the following extreme but illustrative example: if $G_{i}=0.3$ and $\alpha_{i}=4$, then the poverty reduction according to this expression is 120 percent of the initial poverty, implying that the new poverty level is negative.
} 
incorporate both diminishing returns to aid and that poverty is a decreasing but convex function of national income.

If we consider, to start with, only interior solutions (in which each country gets some aid), the first order conditions for a minimum are:

$$
\frac{\partial h_{i}}{\partial A_{i}} N_{i}=\lambda y_{i} N_{i}
$$

Drawing on equation (5), we can rewrite the first order conditions as follows:

$$
-h_{i}^{0} \alpha \varepsilon_{i}\left(1-\frac{A_{i}}{\beta_{i}}\right)\left(1+\varepsilon_{i}\left(A_{i}-\frac{A_{i}^{2}}{2 \beta_{i}}\right)\right)^{-(\alpha+1)}=\lambda y_{i}
$$

As already mentioned, Equation 8 has no algebraic solution. However, since we know the budget constraint (total aid, $a_{t o t}$, is $\$ 149.4 \mathrm{bn}$ in our data), we can numerically solve for the vector of optimal aid levels $\left\{A_{i}^{*}\right\}$ (now allowing for corner solutions).

Next, we assess the poverty reduction that donors could hypothetically achieve by reallocating aid from darling countries (that have received more aid than our allocation rule recommends) to orphan countries (that have received less aid than our allocation rule recommends).

\subsection{Poverty reduction when reallocating aid from darlings to orphans}

Consider the poverty reduction of aid allocated to a particular country. We let $a_{i}$ denote aid to country $i . a_{i}$ and $A_{i}$ thus have the following relationship:

$$
a_{i}=A_{i} y_{i} N_{i}
$$

We denote the marginal poverty reduction of aid, i.e. the extra poverty reduction achieved by one additional aid dollar, $\theta_{i}$ :

$$
\theta_{i}=\frac{\partial\left(h_{i} N_{i}\right)}{\partial a_{i}}=\frac{\partial h_{i}}{\partial a_{i}} N_{i}
$$

Now consider the aid reallocation that would take place if going from the actual to the optimal aid allocation. $a_{i}^{0}$ and $A_{i}^{0}$ refer to actual aid allocated to country $i$, and $a_{i}^{*}$ and $A_{i}^{*}$ refer to the optimal amount of aid country $i$ should get according to our poverty minimizing allocation rule. 
$\theta_{i}^{\text {Reallocated }}$ refers to the average $\theta_{i}$ of the aid that would be reallocated to/from country $i$ when going from the actual to the optimal allocation:

$$
\theta_{i}^{\text {Reallocated }}=\frac{h_{i}\left(A_{i}^{0}\right) N_{i}-h_{i}\left(A_{i}^{*}\right) N_{i}}{a_{i}^{*}-a_{i}^{0}}
$$

Using equation (5) and (9) we can re-write this expression as:

$$
\theta_{i}^{\text {Reallocated }}=-\frac{h_{i}^{0}}{y_{i}} \frac{\left(1+\varepsilon_{i}\left(A_{i}^{*}-\frac{A_{i}^{* 2}}{2 \beta_{i}}\right)\right)^{-\alpha}-\left(1+\varepsilon_{i}\left(A_{i}^{0}-\frac{A_{i}^{0^{2}}}{2 \beta_{i}}\right)\right)^{-\alpha}}{A_{i}^{*}-A_{i}^{0}}
$$

The gain in poverty reduction achieved by the aid reallocated to orphans is $\sum_{i \in \text { Orphans }}\left(\left(a_{i}^{*}-\right.\right.$ $\left.a_{i}^{0}\right) \times \theta_{i}^{\text {Reallocated }}$, and the loss in poverty reduction as a result of the aid reallocated from darlings is $\sum_{i \in \text { Darlings }}\left(\left(a_{i}^{0}-a_{i}^{*}\right) \times \theta_{i}^{\text {Reallocated }}\right)$. The total lost poverty reduction from aid reallocated from the darlings, as percentage of the total gained poverty reduction from the aid reallocated to orphan countries, denoted $\gamma$, is thus given by:

$$
\gamma=\frac{\sum_{i \in \text { Darlings }}\left(\left(a_{i}^{0}-a_{i}^{*}\right) \times \theta_{i}^{\text {Reallocated }}\right)}{\sum_{i \in \text { Orphans }}\left(\left(a_{i}^{*}-a_{i}^{0}\right) \times \theta_{i}^{\text {Reallocated }}\right)}
$$

\subsection{Poverty reducing efficiency across donors}

Next, we distinguish between donor groups and put a value on the poverty reducing efficiency of each donor. Specifically, we calculate the total poverty reduction of aid from each donor, in relation to the volume of total aid given by that donor. Doing so, we get a measure of the average poverty reduction per aid dollar for each donor.

Consider what the marginal poverty reduction of aid $\left(\theta_{i}\right)$ is on average for all aid given to country $i$. $\theta_{i}^{\text {Average }}$ can be expressed as:

$$
\theta_{i}^{\text {Averge }}=\frac{h_{i}\left(A_{i}^{0}\right) N_{i}-h_{i}(0) N_{i}}{a_{i}^{0}}
$$

Using equation (5) and (9) this can be re-written as:

$$
\theta_{i}^{\text {Average }}=-\frac{h_{i}^{0}}{y_{i}} \frac{\left(1+\varepsilon_{i}\left(A_{i}^{0}-\frac{\left(A_{i}^{0}\right)^{2}}{2 \beta_{i}}\right)\right)^{-\alpha}-1}{A_{i}^{0}}
$$


Now consider the aid given by a specific donor $j$ to country $i$, denoted $a_{i}^{j}$. The total poverty reduction of all aid given to country $i$ is $a_{i} \times \theta_{i}^{\text {Averege }}$. Dividing this poverty reduction between donors based on the amount of aid given by each donor suggests that the poverty reduction in country $i$ from aid given by donor $j$ is $a_{i}^{j} \times \theta_{i}^{\text {Averege }}$.

We can now calculate the poverty-reducing efficiency, which we denote $\rho$, of aid from donor $j$ :

$$
\rho_{j=} \frac{\sum_{i}\left(a_{i}^{j} \times \theta_{i}^{\text {Averege }}\right)}{\sum_{i} a_{i}^{j}}
$$

This is the total poverty reduction from aid from donor $j$, in relation to the volume of total aid given by that donor. In other words, it is a measure of average poverty reduction per aid dollar. We finally normalize $\rho_{j}$ by dividing it by $\rho_{\text {All donors }}$ and multiplying the ratio by 100 , denoting the normalized poverty-reducing efficiency $\rho_{j}^{N}$.

$$
\rho_{j}^{N}=100 \frac{\rho_{j}}{\rho_{\text {All donors }}}
$$

This means that, for instance, $\rho_{\text {Canada }}^{N}=166.3$ shall be interpreted as Canada's aid being 66.3 percent more effective at reducing poverty than average aid.

\section{Data and empirical estimation}

In the previous section, we derived a poverty efficient allocation of aid. The next step is to assess the poverty-efficiency of actual aid allocations. As noted, we will first look at aggregate flows, and ask how much poverty could be reduced if aid was allocated according to the specified rule. Next, we break down the analysis by donor groups and flow types and assess the poverty-efficiency of the respective allocations, with a special focus on the comparative impact of new donors and new non-aid flows.

As noted, we find optimal aid using a numerical solution to the first order condition specified in equation (8). ${ }^{8}$ For this purpose, we need data on aid flows, poverty and policy, as well as other development outcomes. To begin with, we compile a large amount of aid data, grouping the included donors into two main categories. First, we refer to the traditional donors, that is bilateral DAC donors, the EC, UN, WB, IMF, Regional Development Banks, and other

\footnotetext{
${ }^{8}$ To find the numerical solutions, we use a loop within a loop (based on the Newton-Raphson method) in Stata.
} 
multilateral donors (except Vertical Funds), ${ }^{9}$ as well as to non-governmental organizations (NGOs) as 'old aid'. Second, we classify the bilateral non-DAC donors and New Global Actors (specifically, the Bill and Melinda Gates Fund and Vertical funds) as 'new donors'.

With respect to the first category, the data on aid from the traditional multilateral and DAC bilateral donors is from the AidData Research Release 3.1 dataset (AidData, 2017a). Part of the data on aid from International NGOs is from Koch et al. (2009). While this data includes only a subset of NGOs, it is to our knowledge the most recent and comprehensive dataset on aid from international NGOs. In addition, we have compiled novel data (covering 2009-2013) on aid from Doctors without borders (MSF) and from the International Red Cross (ICRC), directly from the organizations in question (Médecins Sans Frontières, 2010, 2011, 2012, 2013, 2014; International Committee of the Red Cross, 2010, 2011, 2012, 2013, 2014).

The AidData Research Release 3.1 dataset (AidData, 2017a) also contains data on aid from a great number of non-DAC bilateral donors, ${ }^{10}$ and from the New Global Actors, relevant for our second category, 'new donors'. The data on aid from the non-DAC bilateral donors China, Saudi Arabia and Qatar are from separate datasets, however (AidData 2014a, 2014b, 2017b). Since these countries do not release official, project-level financial information about its foreign aid activities, this data is based on an open-source media based data collection technique that triangulates project information across a range of data sources. ${ }^{11}$ Finally, data on aid from the non-DAC bilateral donors Bulgaria, Croatia, Israel, Kazakhstan, Russia and Turkey is from OECD-DAC (2020), since data on these flows is not available from AidData.

When possible, we focus on average (Commitments in Current USD) Official Development Assistance (ODA) 2009-2013. In order to qualify as ODA, an aid flow must be concessional, have a grant element of at least 25 percent, and its main objective should be the promotion of economic development of developing countries (OECD, 2016). For China, Saudi Arabia and Qatar we focus on flows judged as 'ODA-like' by AidData coders (see Strange et

\footnotetext{
${ }^{9}$ Vertical funds are development financing mechanisms focused on single development domains and drawing on mixed funding sources (Future UN Development System, 2015). The following Vertical Funds are included: The Global Fund to Fight AIDS, Tuberculosis and Malaria (GFATM), the Global Alliance for Vaccines and Immunization (GAVI), and the Global Environment Facility (GEF).

10 Brazil, Bulgaria, Chile, China, Colombia, Croatia, Estonia, India, Israel, Kazakhstan, Kuwait, Latvia, Liechtenstein, Lithuania, Monaco, Qatar, Russia, Saudi Arabia, South Africa, Taiwan, Thailand, Turkey and the United Arab Emirates. We also classify the Czech Republic, Hungary, Iceland, Poland, the Slovak Republic and Slovenia as Non-DAC bilateral donors, since these countries were not DAC-members for most of the period under study (2009-2013).

${ }^{11}$ While information from public media outlets is of course an imperfect substitute for complete statistical data from official sources, Strange et al. (2017) provide a careful description of how they dealt with challenges in the data collection process. See also Muchapondwa et al. (2014), for a validation of the Chinese data using a 'groundtruthing' methodology.
} 
al., 2017). In other cases, (Brazil, Chile, Colombia, Hungary, India, Latvia, Liechtenstein, Lithuania, Monaco, South Africa, Taiwan and Thailand) ODA-status is not specified. In cases when a donor lacks data on aid flows for some year/s 2009-2013, we use an average of as many, and as recent, years as possible. We include only flows that actually constitute a transfer of money or resources from the donor country to the recipient country, meaning that we exclude e.g. 'Administrative Costs of Donors', 'Action Relating to Debt', 'Refugees in Donor Countries', 'Scholarships/training in the donor country' and 'Promotion of development awareness'.

On the recipient side, we include the countries part of the DAC list of ODA recipients (OECD, 2021) for at least one of the years 2009-2013. We exclude regional aid that cannot be tied to a specific recipient country. Furthermore, we exclude India as an aid recipient since the country, while receiving aid, is simultaneously a major emerging donor. After sample restrictions, we end up with a total sum of 149.4 billion USD that donors could seek to allocate optimally.

Considering the changing aid landscape, where the role of traditional ODA is becoming less dominant (OECD, 2014), we also explore the role of non-aid flows for the poor underfunded countries. In particular, we consider 'Other Official Flows' (OOF), transactions by the official sector which do not meet the previously described conditions for eligibility as ODA, obtained from AidData, and personal remittances and foreign direct investment (FDI), obtained from the World Development Indicators (WDI, World Bank, 2019b).

To assess the poverty reducing efficiency of actual aid allocation patterns, we need data on poverty. In our benchmark estimations, we use a poverty index based on GNI (PPP adjusted) per capita, obtained from the WDI (World Bank, 2019b). The rationale for this is partly that richer countries with high poverty should be held accountable for their unequal distribution of income (Sterck et al., 2017; Bigsten and Tengstam, 2015), and partly the relative robustness of the indicator (poverty rates tend to vary considerably based on the specific indicator used). In the sensitivity analysis, we nevertheless use headcount poverty, $\$ 1.90$ (PPP) a day as well as $\$ 3.10$ (PPP) a day as alternative measures (also from WDI).

To incorporate policy, while taking into account structural economic vulnerability and low human capital (see the discussion in Section 2.1), we use the augmented CPR (ACPR) proposed by Guillaumont et al. (2017a) in our benchmark calibration. As noted, the ACPR is a weighted average of the original CPR of the World Bank and the Economic Vulnerability Index (EVI) and Human Assets Index (HAI) used by the UN to identify LDCs (United Nations, 2019a). In 
the robustness analysis, however, we also run estimations using the standard country performance rating (CPR) of the World Bank (IDA, 2017b).

We obtain figures on GDP per capita and population from the World Development Indicators (World Bank, 2019b). Finally, we use a group of indicators to find predicted values of variables for which we have missing values. For a summary of variable definitions and data sources, see Table A1, and for descriptive statistics of key variables, see Tables A2-A5.

Among the aid recipient countries, we identify aid darlings and aid orphans, and assess to what extent new donors and non-aid flows contribute to a more or less poverty-efficient allocation. An 'aid orphan' here refers to a country that receives less aid than our allocation rule recommends. To reduce poverty more effectively, the donor community should scale up aid to these countries. Correspondingly, an 'aid darling' is a country that gets more aid than our allocation rule recommends, implying that the donor community should scale down aid to these countries.

While we present what may seem like exact figures, it is important to remember that optimal aid allocation estimations are sensitive to using different model specifications and measures. To get a sense of the sensitivity of our benchmark findings, we perform a battery of robustness checks. As noted, these entail using different elasticities of poverty with respect to income $(\alpha)$ and different aid/GDP saturation points for a nation with average policy $\left(\beta_{0}\right)$, as well as incorporating and measuring policy and poverty in several different ways.

Using three different values for $\alpha$ (1.0 and 2.0, on top of the benchmark value of 1.5) as well as for $\beta_{0}$ (20 and 30 percent on top of the 25 percent benchmark) gives nine ( $\left.3 \times 3\right)$ different calibrations. With respect to poverty, on top of a poverty index based on GNI/cap (PPP) we also use the headcount ratio at $\$ 1.90$ and $\$ 3.10$ a day (PPP), respectively. For policy, we use CPR as an alternative to ACPR. Finally, we incorporate policy using three different policy factors. ${ }^{12}$ In total, this gives $162(3 \times 3 \times 3 \times 3 \times 2)$ different calibrations. For the sake of brevity, we present only the extreme values obtained for each recipient country, which we interpret as upper and lower bounds on their estimates. This also allows us to present upper and lower bounds for the estimates in the analysis by donor groups.

Based on these, we modify the above darling/orphan classification. Countries that are orphans (i.e. receive less aid than the allocation rule specifies) in all calibrations we refer to as 'pure orphans', and countries that are darlings (i.e. receive more aid than the allocation rule

\footnotetext{
12 Drawing on Collier and Dollar (2002) we use a benchmark 'policy factor' of 0.67 , and the alternative policy factors 0.38 and 1.06 in the robustness analysis (see Appendix B for details).
} 
specifies) in all calibrations we refer to as 'pure darlings'. Countries that are orphans in the benchmark calibration, but darlings in some robustness calibration/s we refer to as 'borderline orphans', and correspondingly, countries that are darlings in the benchmark calibration, but orphans in some calibration/s we refer to as 'borderline darlings'.

\section{Results}

In this section, we assess the poverty-efficiency of actual aid allocations. First, we consider aggregate flows, and ask how much poverty could be reduced if aid was allocated according to the specified rule. Second, we break down the analysis by donor groups and flow types and assess the poverty-efficiency of the respective allocations, with a special focus on the comparative impact of new donors and new non-aid flows. Finally, we assess to what extent new donors and non-aid flows contribute to a more or less poverty-efficient allocation.

\subsection{Benchmark results}

Looking at Figure 1, we can note that there is no clear negative relationship between aid per capita and GNI (PPP) per capita among aid receiving countries. Hence, in line with our introductory discussion, there is no indication that the poorest countries in the sample receive most aid and that the richest countries receive least aid. Rather, there is great variation in the amount of aid received among the very poor (compare e.g. Mozambique and the DRC) as well as among the relatively rich (compare e.g. Tunisia and Peru). While Figure 1 is purely descriptive - in particular, it does not incorporate the role of policy - it demonstrates that there are winners and losers in terms of the amount of aid received in relation to country income.

Figure 2 instead shows the optimal amount of aid each country should get according to the allocation rule, again in relation to their GNI (PPP) per capita. Comparing the two graphs again highlights the existence of winners and losers. Figure 3 makes the comparison more explicit, showing both the actual aid received and the optimal aid a country should get according to the allocation rule for 14 example countries. We can for instance note that the low level of aid the DRC receives in relation to their national income actually corresponds with their specified optimal level of aid, due to their low policy scores and thus low assumed aid/GDP saturation point. Others stand out as clear aid orphans. Consider Tanzania. According to the allocation rule, they should receive $183 \mathrm{USD} /$ capita, but in practice, they only receive 81 . At the other 
end of the spectrum, among the aid darlings, countries like Tunisia, Morocco, Egypt and Turkey receive substantial aid volumes, while according to our allocation rule they should receive none.

Table 1, which shows the actual and optimal aid allocation across orphan and darling countries as defined in Section 4, provides an aggregate picture of our results. The optimal aid allocation (Column 2) and recommended change (Column 5) are based on our benchmark calibration. The upper and lower bounds (Columns 3-4 and 6-7), which will be discussed further in the next section, are derived from the sensitivity analysis. The results suggest a substantial misallocation of aid. Specifically, the benchmark calibration suggests that donors should reallocate 73.5 billion USD from the darling to the orphan countries. Thus, according to our poverty minimizing allocation rule, nearly half of the total aid budget of 149.4 billion USD is misallocated. These figures are clearly alarming.

Our model predicts that the suggested reallocation of aid would come with significant gains in terms of poverty reduction. Based on equation (13), we can conclude that the average poverty reducing effect of the proposed decrease in aid to the darling countries is only 4.4 percent of the equivalent effect in the orphan countries. We can think of the foregone poverty reduction in the darling countries $-0.044 * 73.5=3.2$ billion USD - as the cost of the proposed reallocation, which in turn implies that the net benefit of the reallocation would be $73.5-3.2=$ 70.3 billion USD. ${ }^{13}$ This means that the proposed reallocation of aid could reduce poverty by as much as if the total aid volume would increase by 70.3 billion USD (allocated optimally). The overall picture from our benchmark calibration, based on a comprehensive dataset including a large group of new donors, is thus that today's aid allocation pattern is very inefficient in terms of poverty reduction, and that there are substantial gains to be made by reallocating aid from darling to orphan countries.

A potential objection is that optimal aid allocation estimations are likely to be sensitive to different calibrations, e.g. to using different elasticities of poverty with respect to income, different aid/GDP saturation points, and to measuring and incorporating policy and poverty in different ways. In a next step, we take the sensitivity of our findings into account.

\footnotetext{
${ }^{13}$ In the sensitivity analysis, we find a lower bound of 0.9 percent and an upper bound of 17.6 percent, giving a net benefit in the interval $60.6-72.8$ billion USD.
} 


\subsection{Conservative estimates}

Based on extensive sensitivity analysis, we divide the aid receiving countries in our sample into pure and borderline orphans, and pure and borderline darlings (see Figure 4). For conservative estimates, let us consider only the pure orphans/darlings, i.e. the countries that receive less/more aid than the allocation rule specifies in all 162 calibrations. Tables 2 and 3 present the optimal aid allocation to pure orphans and darlings, broken down by country.

As seen in Table 2, the pure orphans consist of 11 countries. All our estimations suggest that in order to reduce poverty, one should scale up aid to these countries. Today, the total aid to the pure orphan countries amounts to 26 billion USD. According to our benchmark calibration, however, they should receive approximately 65 billion USD, implying a suggested reallocation of nearly 39 billion USD, or 150 percent. In absolute terms, the most seriously underfunded countries in relation to their recommended optimal aid level are (in order) Bangladesh, Tanzania, Ethiopia, Kenya, and Zambia. In Bangladesh, the recommended aid level is more than four times the size of the amount received. In Tanzania, the recommended aid level is more than twice that received. Roughly speaking, the same goes for most countries in the group. Hence, in relative terms, the recommended increases are overall substantial. The highest recommended aid-percent is 33.8 percent of GDP to Burkina Faso. Looking at the upper and lower bounds for optimal aid, we see that the confidence intervals are quite wide. However, at the very least, i.e. considering only the lower bound estimates, the estimations suggest an increase of 14 billion USD going to the pure orphans.

At the other end of the spectrum, 91 of our 152 sample countries receive more aid than the allocation rule specifies in all 162 calibrations and are thus classified as pure darlings (see Table 3). Today, total aid to this group of countries amounts to 60.4 billion USD. According to our benchmark poverty efficient allocation, however, they should receive only 6.9 billion, i.e. less than 12 percent of the actual amount obtained. Indeed, considering the upper and lower bounds for the optimal aid estimates (Columns 9-10), we can note that for most countries in this group, the recommendation is zero aid in all calibrations. We find the largest recommended decrease, in absolute terms, in Egypt (6.1 billion USD). Another notable case is Turkey, which in spite of being an upper middle-income country, receives 4.6 billion USD in aid, rather than as recommended in all calibrations of the poverty efficient allocation: zero.

The pattern illustrates the multiple objectives of donors. The US, for instance, views Egypt as an important ally in the region, helping to counteract military threats from other Arab states against Israel (Al Jazeera, 2017). Egypt's domestic stability, both economic and military, is 
thus in the interest of the US. A similar story applies to Turkey, with its strategic position connecting Eastern Europe and West Asia, and bordering several Middle Eastern countries involved in military conflict in the region. Furthermore, some large aid flows, such as those to Haiti after the massive 2010 earthquake, are motivated by humanitarian emergencies. For others, consider e.g. the aid to war-torn Afghanistan, there are likely both strategic and humanitarian motives involved.

While the allocation of aid among countries clearly reflects multiple objectives, the relatively large aid flows to many middle income countries in this group go against the official donor emphasis on poverty reduction. If we again take a cautious approach, and consider only the lower bound estimates, the estimations suggest decreasing the amount of aid going to this group of countries by 46.7 billion USD. According to our lower bound estimate, 31 percent of the total aid budget is thus misallocated.

For the sake of brevity, we present the results for the optimal aid allocation to borderline orphans and darlings, broken down by country, in the appendix (Tables A6-A7). We have 25 borderline orphans in our sample. As noted, these countries receive less aid than the allocation rule specifies in the benchmark calibration, but more aid than our allocation rule specifies in at least one robustness calibration. Considering that we run 162 different calibrations, this is indeed a tough test. The reasons why these countries turn out borderline cases differ.

For some, it is a question of a weak policy environment. Despite widespread poverty and aid levels that under normal circumstances (average policy scores) would be far below the saturation point, calibrations giving high weight to policy scores still suggest reducing aid to these countries (consider e.g. Chad, Eritrea, DRC, Guinea-Bissau, Guinea, Togo, and Madagascar). This group of countries arguably highlights the need to find aid modalities that can help reduce poverty in unstable policy environments (e.g. support through NGOs), or for that matter, the importance of strengthening governance.

For other countries with very low incomes (e.g. Gambia, Malawi, Mozambique, Niger, Rwanda, and Sierra Leone), it is rather a question of being close to the lowest saturation point used in our alternative calibrations. If we choose to trust the most conservative calibrations, one could argue that these countries highlight the importance of increasing the aid absorptive capacity of the poorest countries. Notably, while these countries do not receive very large volumes of aid in per capita terms, their low levels of GDP still imply comparatively high shares of aid in GDP.

Finally, a number of countries are simply borderline cases in terms of poverty. In some countries, the different poverty measures point in different directions (e.g. Nigeria and Nepal), 
in other cases, all measures suggest borderline poverty levels (notable Vietnam, Ghana, Nicaragua, and Mauritania).

\subsection{Donor comparisons}

The donors included in the analysis, ranging from small bilateral actors to large multilaterals organizations and other global players, are by no means homogenous. Indeed, a common argument is that bilateral aid is often tied to the political agenda of the donor country, whereas multilateral donors are often seen as more impartial (see the discussion in Charron, 2011). In this section, we break down the analysis by donor groups and assess the poverty-reducing efficiency of the respective allocations.

We calculate the total poverty reduction of aid from each donor, in relation to the volume of total aid given by that donor, giving a measure of average poverty reduction per aid dollar. We standardize the average poverty reducing efficiency to 100 , implying that a country with an estimated poverty reducing efficiency of, say, 120 is 20 percent more effective at reducing poverty than aid on average (see equation (17)). Table 4 presents the results, by donor groups.

The poverty-reducing efficiency in column 2 varies considerably across the specified groups. In line with the above argument, suggesting that bilateral aid is to a greater extent motivated by strategic political considerations, both the DAC and, particularly, the non-DAC bilateral donors perform worse than average in terms of poverty-reducing efficiency. The multilaterals - with the World Bank and the UN at the forefront - as well as the new global actors and the NGOs, are more efficient than average. The exception is aid from the EC, which is significantly below average in terms of poverty-reducing efficiency, possibly reflecting an influence of strategic rather than poverty focused considerations of EC member countries.

There is also considerable variation across donors within groups. In the interest of space, we present the detailed tables, broken down by individual donors, in the appendix (see Table A8). However, we can note some interesting patterns. Among the bilateral DAC-donors the variation is huge. Considering the G7 countries, the allocations of the UK and Canada perform clearly above average, whereas those of Japan, France and Germany perform clearly below (the US and Italy are close to average). Comparing the allocations of the UK and France is particularly striking; the estimations suggest that an aid dollar from the UK is 190 percent more efficient in terms of reducing poverty than an aid dollar from France. The allocations of 
Belgium, Ireland, Portugal, the Netherlands and the Nordic countries are all well above average. ${ }^{14}$

China stands for a third of all non-DAC bilateral aid. In terms of the poverty-reducing efficiency of their allocation, they actually perform clearly above average, probably reflecting their relative focus on African countries. Hence, in line with the findings of Dreher et al. (2018), which suggest that Chinas motives are not substantially different from those shaping the allocation of Western aid, these estimates provide no support for worries that China is less poverty oriented than the traditional bilateral DAC donors. The poverty-reducing efficiency of aid flows from the central European nations Hungary, the Slovak Republic, Slovenia, Poland and the Czech Republic (small donors that have become DAC members after the time span considered in this study), are all considerably below average. Finally, Brazil and South Africa (both small donors in terms of volumes) are much more efficient than average, whereas Saudi Arabia, UAE, Kuwait, Qatar and Turkey (together capturing 59 percent of all bilateral nonDAC aid) are much less efficient than average.

Taking into account the sensitivity of estimates does not change this picture very much. The upper and lower bounds of the individual donor estimates tell us that the magnitudes should be interpreted as roughly $+/-20$ percent in general. For example, while the benchmark estimate suggests that Canada's poverty-reducing efficiency is 66 percent above average, the lower and upper bounds are 40 and 90 percent respectively. However, since most donors' scores move in the same direction between different calibrations, the relative efficiency across donors is more stable than these intervals would seem to suggest.

In the next section, we have a closer look at the role of the 'new donors' and the new financial flows (NFFs).

\subsection{Focusing on the new donors and new financial flows}

Next, we are interested in whether the new actors and sources of development finance on the development arena help counteract the relative neglect of some countries in the distribution of aid. In relative terms, do these new flows help alleviate, or add to, the observed misallocation of aid? In absolute terms, are the flows to aid orphans large enough to compensate for the lack of aid?

\footnotetext{
${ }^{14}$ The variation between different NGOs is similarly large. For example, MSF and Welt Hunger Hilfe score about 3 - 6 times higher than Oxfam and World Vision.
} 
With respect to the 'New Donors', we have seen that the non-DAC bilateral donors perform clearly below and the new global actors well above average in terms of poverty reduction per aid dollar. While evidently no homogenous group, together the new donors perform below average in terms of relative poverty reducing efficiency. To get a picture of to what extent they contribute to poverty reduction, however, we also need to consider aid volumes. Column 5 in Table 4 gives the proportion of total poverty reduction - defined as poverty reduction efficiency per aid dollar multiplied by the total aid volume - achieved by each donor or donor group.

We can note that even though the estimated poverty reduction per aid dollar among the bilateral non-DAC donors is only 63.5 percent of the average poverty reducing efficiency, they stand for a rather significant share $\left(9.1\right.$ percent) of overall poverty reduction. ${ }^{15}$ On the other hand, even though the poverty reducing efficiency per aid dollar among the New Global Actors is 44.1 percent higher than average, they stand for a quite modest share (around 5.5 percent) of overall poverty reduction. The reason, of course, lies in the relatively large aid volumes from the non-DAC donors and the relatively modest aid flows from the New Global Actors. Taken together, the new donors contribute to an estimated 14.6 percent of overall poverty reduction. While not a total game changer, this it is clearly not negligible.

Knowing that the part played by traditional official development assistance (ODA) in development cooperation is becoming less dominant (OECD, 2014), we next turn to the role of other international flows. We consider three kinds of new financial flows (NFFs): OOF, FDI and Personal Remittances. Including both state flows, commercial flows, and transfers within families, NFF is clearly a very heterogeneous category including flows that presumably take place for widely different reasons. As such, NFFs are not directly comparable to aid, and we thus cannot apply the same analytical framework as that used to assess the poverty reducing efficiency of aid. For instance, we have no reason to assume the same saturation points, or poverty elasticities with respect to income, for these flows as for aid. Nonetheless, it is interesting to explore whether NFFs help counteract the observed misallocation of aid.

Hence, we compare the distributional profiles of the NFFs to those observed for aid. Column 6 in Table 4 gives the average poverty in the NFF-receiving (and for comparison, aidreceiving) countries, weighed by financial flow volume. ${ }^{16}$ Among the NFF-receiving countries,

\footnotetext{
${ }^{15}$ For equivalent figures on individual donor countries, see Table A8.

16 Average poverty weighed by finacial flow volume $=\frac{\sum_{i}\left(\text { flow }_{i} \times \text { Povert }_{i}\right)}{\sum_{i} \text { flow }_{i}}$ where flow $w_{i}$ refers to the respective flows of $O O F_{i}$, remittances $s_{i}$ and $F D I_{i}$ going to country $i$ (and correspondingly, for comparison, the respective aid flows).
} 
average poverty is in the range of 10-14 percent (lowest for FDI and OOF, highest for remittances). Considering the corresponding figures for aid-receiving countries, which range between 15 ("Other multilateral donors") and 35 (the World Bank and New Global Actors) percent, it is clear that NFFs have a significantly lower poverty focus than aid.

Another way to assess the distributional profiles of the new donors and new financial flows, is by considering to what extent they go to the most underfunded countries. Table 5 presents the allocation of aid and other flows across orphan and darling countries, in absolute value (USD per capita) as well as a share of the total flow type. ${ }^{17}$ For the sake of brevity, we focus primarily on the most under-funded group, i.e. the pure orphans. However, the corresponding figures for the other recipient country groups - borderline orphans, borderline darlings and pure darlings - are included for comparison. As a point of reference, we can note that out of all aid from Traditional donors, about 19 percent goes to pure orphan countries. In terms of volumes, this amounts to around 49 USD per capita.

Among the new donors, in comparison, only 8 percent of the bilateral non-DAC aid goes to the pure orphan countries. In line with our previous discussion, the New Global Actors perform significantly better in relative terms, with 24 percent of their aid going to the most underfunded group. In dollar terms, both the contribution of the non-DAC bilateral donors (4 USD per capita) and that of the New Global Actors (3 USD per capita) are relatively minor, however.

Turning to the new financial flows, we can note that the volume of OOF going to the pure orphan countries is relatively modest. On average, the pure orphans receive about 9 USD per capita in OOF. In USD per capita terms, all aid flows tend to be larger (although, per definition, not large enough according to our allocation rule) among orphan countries than among darling countries, reflecting that the former group of countries tend to be significantly poorer than the latter. Notably, however, this is not true for OOF, which in per capita terms is lowest in the pure orphan group. Indeed, it is more than 50 percent higher in the borderline orphan group, and twice the size in the two darling groups.

\footnotetext{
${ }^{17}$ Note that these figures are somewhat difficult to interpret on their own. In general, comparing the allocations of different flow types to a specific group of recipient countries is more informative than comparing the allocation of a specific flow type across groups. For instance, comparing the share of aid vs. the share of OOF going to the most underfunded group (pure orphans), gives a picture of their respective poverty focus. Comparing the shares of a specific flow type, say OOF, going to the orphan and darling groups is, on the other, not very informative, since the orphan and darling groups contain different numbers of countries, with different size populations. Similarly, comparing the USD per capita measures of a specific flow type across the orphan and darling groups is of limited relevance, seeing that the table provides no information about recipient country poverty levels. Again, however, comparing the USD per capita contributions of different flow types to the most underfunded group helps to shed light on to what extent they help alleviate or add to the observed misallocation of funds.
} 
For FDI, this pattern is even more striking; the average FDI per capita in the pure orphan group (17 USD) is only 9 percent of that in the pure darling group (195 USD). Furthermore, the volumes are again relatively modest; considering FDI and OOF together, they amount to less than half of what the most underfunded countries receive in aid per capita. Considering that poverty reduction is no objective of these flows, this is not necessarily surprising. Nonetheless, it is difficult to argue that OOF and FDI substitutes for aid in this vulnerable group. On the contrary, rather than counteracting the relative neglect of the pure orphans in the allocation of aid, these flows add to the inequitable distribution.

Do personal remittances help make up for the allocation problem at hand? Seemingly no. On the one hand, compared to the limited amounts of OOF and FDI to the pure orphan group, these flows are larger in per capita terms. Again, however, the flow type is smallest in the most underfunded group. Furthermore, even if the aggregate picture had been more equitable, personal remittances are unlikely to reach the poorest segments of the population within countries. Once again, then, these flows cannot be said to substitute for aid in the most underfunded countries.

Considering the flow shares going to the pure orphan countries confirms the picture that the NFFs have a comparatively weak poverty focus. Compared to the 17.4 percent of total aid going to the pure orphan countries, the shares of the respective NFFs that go to the same group of countries range from 1.3 percent (FDI) to 6.8 percent (remittances). While hardly surprising (ODA should, by definition, have development intent and thus be more poverty focused), this goes to show that NFFs cannot be said to substitute for aid in the most underfunded countries.

In sum, neither the new donors nor the new financial flows alleviate the observed misallocation of aid. While the new donors stand for a non-negligible share of overall poverty reduction, they perform below average in terms of poverty reduction per aid dollar, and their share in total aid is smaller in the orphan than in the darling countries. Similarly, rather than counteracting the relative neglect of the pure orphans in the allocation of aid, the NFFs considered here add to the inequitable distribution. Furthermore, the size of these alternative flows are not significant enough to substitute for the lack of aid to this group.

\section{Conclusions}

While poverty reduction takes center stage among official donor objectives, the poorest countries are not necessarily the ones receiving most aid. In this study, we explored whether the changing aid landscape, where new actors and sources of development finance are 
becoming increasingly influential, has helped achieve a more poverty efficient allocation of aid. Specifically, we derived a poverty-minimizing allocation of aid, based on which we assessed the poverty-efficiency of actual aid allocations, with a special focus on the comparative impact of new donors and new non-aid flows.

Our poverty-minimizing aid allocation rule has a number of key features. In line with the pioneering work of Collier and Dollar $(2001,2002)$, it is specified so that holding the level of poverty constant, aid should increase with the quality of policy, and holding the quality of policy constant, it should increase with poverty. However, rather than deriving an allocation rule that maximizes poverty reduction via growth, which can be questioned on both theoretical and empirical grounds, we allow aid to have a direct effect on income. As is standard in the literature, we assume aid to have diminishing returns. Furthermore, we assume that the saturation point for consumption-aid is the same as that for growth-aid. To take account of structural economic vulnerability and low human capital, finally, we use an augmented policy rating rather than the standard CPR. To assess the sensitivity to using different model specifications and measures, we perform a battery of robustness checks.

Considering aggregate flows, our baseline results suggest a substantial misallocation of aid. Specifically, the benchmark calibration suggests that donors should reallocate 73.5 billion USD, i.e. nearly half the total aid budget, from countries receiving more aid than our allocation rule specifies - referred to as aid darlings - to countries receiving less aid than our allocation rule specifies - referred to as aid orphans. Our estimates suggest that this reallocation of aid could reduce poverty by as much as if the total aid volume would increase by 70.3 billion USD (allocated optimally). The overall picture from our benchmark calibration, based on a comprehensive dataset including a large group of new donors, is thus that today's aid allocation pattern is very inefficient in terms of poverty reduction, and that there are substantial gains to be made by reallocating aid from darling to orphan countries.

Acknowledging that optimal aid allocation estimations are likely to be sensitive to different calibrations, we carefully evaluate the sensitivity of these estimates. Using different elasticities of poverty with respect to income, different aid/GDP saturation points, and measuring and incorporating policy and poverty in different ways, we end up with 162 calibrations in total. Based on these, we establish upper and lower bounds on our estimates. Specifically, we divide the aid receiving countries in our sample into pure orphans and darlings, and borderline orphans and darlings, where the former receive less/more aid than the allocation rule specifies in all 162 calibrations whereas the latter change status in some robustness calibration. For conservative estimates, we consider only the pure orphans/darlings. 
In our sample of 152 aid-receiving countries, we identify 11 pure orphans and 91 pure darlings. All our estimations suggest that in order to reduce poverty, one should reallocate aid from the latter to the former. Notable pure orphan countries are Bangladesh, Tanzania, Ethiopia, Kenya, and Zambia. In Bangladesh, the recommended aid level is more than four times the size of the amount received. While the allocation of aid among countries clearly reflects multiple objectives, the relatively large aid flows to many middle income countries in the pure darling group go against the official donor emphasis on poverty reduction. If we take a cautious approach, and consider only the lower bound estimates, the results suggest decreasing the amount of aid going to this group of countries by 46.7 billion USD. According to our lower bound estimate, 31 percent of the total aid budget is thus misallocated.

The estimated poverty-reducing efficiency, or the average poverty reduction per aid dollar, varies considerably across donor groups. Whereas the multilaterals - with the World Bank and the UN at the forefront - as well as the new global actors and the NGOs, are more efficient than average, the bilaterals, both DAC and (even more so) non-DAC, as a group perform worse. However, there is equally important variation across donors within groups, with e.g. the World Bank performing significantly better in terms of poverty reducing efficiency than the EC among the multilaterals, and e.g. the UK and Canada performing better than France and Germany among the major bilaterals.

Turning to the new donors and the new financial flows, we should note that both constitute very heterogeneous categories. Regarding the new donors, the new global actors perform well above average and the non-DAC bilateral donors clearly below in terms of poverty reducing efficiency. The NFFs similarly include very diverse flows and actors, guided by very different motivations. Indeed, the NFFs are by no means directly comparable to aid. Nonetheless, we are interested in whether these flows help counteract the observed misallocation of aid.

Overall, neither the new donors nor the new financial flows alleviate the observed misallocation of aid. While it is worth noting that new donors stand for a non-negligible share of overall poverty reduction, together they perform below average in terms of poverty reduction per aid dollar. Similarly, rather than counteracting the relative neglect of the pure orphans in the allocation of aid, the New Financial Flows add to the inequitable distribution. For the countries that we identify as aid orphans, these flows are simply not significant enough to substitute for the lack of aid.

Our findings thus suggest that the traditional donor community cannot rely on the new donors and non-aid flows to compensate for the relative neglect of the most underfunded countries in the distribution of aid. To live up to official donor objectives to 'end poverty in all 
its forms everywhere' donors should, well, not kill their darlings, but at least reallocate a considerable share of their aid from darling to orphan countries.

\section{References}

AidData (2014a) "Saudi Arabia TUFF Donor Dataset, Version 1.0", available at: https://www.aiddata.org/data/saudi-arabia-tuff-donor-dataset-level-1-v1-0

AidData (2014b) "Qatar TUFF Donor Dataset, Version 1.0", available at: https://www.aiddata.org/data/qatar-tuff-donor-dataset-level-1-v1-0

AidData (2017a) “AidDataCore_ResearchRelease_Level1_v3.0 Research Releases dataset", Williamsburg, VA : AidData, available at: https://www.aiddata.org/data/aiddata-coreresearch-release-level-1-v3-0

AidData (2017b) "Global Chinese Official Finance Dataset, Version 1.0". available at: http://aiddata.org/data/chinese-global-official-finance-dataset.

Alesina, A. and D. Dollar (2000) "Who Gives Foreign Aid to Whom and Why?" Journal of Economic Growth, 5 (1), pp. 33-63.

Alesina, A. and B. Weder (2002) "Do Corrupt Governments Receive Less Foreign Aid?", American Economic Review, 92(4), pp. 1126-1137.

Arndt, C., S. Jones and F. Tarp (2010) "Aid, growth and development: Have we come full circle?", Journal of globalization and development, 1(2), pp. 1-27.

Al Jazeera, 2017 "Why US aid to Egypt is never under threat", F. Najjar, Al Jazeera, Oct. 3 2017, available at: https://www.aljazeera.com/news/2017/10/aid-egypt-threat171002093316209.html (accessed 2019-09-23).

Bigsten, A., and A. Shimeles (2007) "Can Africa Reduce Poverty by Half by 2015?'. Development Policy Review, 25(2), pp. 147-66.

Bigsten, A. and S. Tengstam (2015) "International coordination and the effectiveness of aid", World Development, Vol 69, May 2015, pp. 75-85.

Bourguignon, F. (2000). “The Pace of Economic Growth and Poverty Reduction'. Paris: DELTA. Mimeo.

Bourguignon and Gunning (2016) "Foreign aid and governance: a survey", EDI Working Paper Series, WP16/10. Available at: https://edi.opml.co.uk/resource/foreign-aid-governancesurvey/. 
Bourguignon and Platteau (2017) "Does aid availability affect effectiveness in reducing poverty?", World Development, vol 90, p 6-16.

Burnside, C. and D. Dollar (2000) “Aid, Policies, and Growth”, American Economic Review, 90(4), pp. 847-868.

Carter, P. (2014) “Aid allocation rules”, European Economic Review, vol. 71, pp. 132-151.

Charron, N. (2011) "Exploring the impact of foreign aid on corruption: Has the "anti-corruption movement" been effective?", The Developing Economies, 49(1), pp. 66-88.

Clemens, M. A., S. Radlet, R. R. Bhavnani and S. Bazzi (2012) "Counting chickens when they hatch: timing and the effects of aid on growth", Economic Journal, 122, pp. 590-617.

Cogneau, D., and J. D. Naudet (2007) "Who deserves aid? Equality of opportunity, international aid, and poverty reduction”, World Development, 35(1), pp. 104-120.

Collier, P. and D. Dollar (2001). "Can the world cut poverty in half? How policy reform and effective aid can meet the international development goals", World Development, vol. 29 (11), pp. 1787-802

Collier, P. and D. Dollar (2002) “Aid Allocation and Poverty Reduction”, European Economic Review, 29(11): 1787-802.

Collier, P. and D. Dollar (2004) “Development effectiveness: what have we learnt?” Economic Journal, 114 (496), pp. 244-271.

Dalgaard, C., H., Hansen and F. Tarp (2004) “On the Empirics of Foreign Aid and Growth", Economic Journal, 114(496), pp. F191-F216.

Dollar, D. and V. Levin (2006) “The Increasing Selectivity of Foreign Aid, 1984-2003”, World Development, 34 (12), pp. 2034-46.

Dreher, A., Fuchs, A., Parks, B., Strange, A. M. and M. J. Tierney (2018) “Apples and Dragon Fruits: The Determinants of Aid and Other Forms of State Financing from China to Africa”, International Studies Quarterly, 62(1), pp. 182-194.

Easterly, W. (2003) “Can foreign aid buy growth?”, Journal of Economic Perspectives, 17(3), pp. $23-48$.

Easterly, W., Levine, R. and D. Roodman (2004) "Aid, policies, and growth: comment", American Economic Review, 94(3), pp. 774-80.

Future UN Development System (2015) "Vertical funds: lessons for multilateralism and the UN", Briefing 25, January 2015, accessed 2021-11-08 at: https://www.futureun.org/media/archive1/briefings/FUNDS_Brief25_Jan2015_WHO_G AVI_GF.pdf 
Guillaumont, P., S. Guillaumont Jenneney and L. Wagner (2017a) "How to take into account vulnerability in aid allocation criteria and lack of human capital as well: improving the performance based allocation”, World Development, vol 90. pp. 27-40.

Guillaumont, P., M. McGillivray and L. Wagner (2017b) "Performance assessment, vulnerability, human capital, and the allocation of aid among developing countries", World development, vol. 90, pp. 17-26.

Guillaumont, P. and L: Wagner (2014), “Aid Effectiveness for Poverty Reduction: Lessons from Cross-country Analyses, with a Special Focus on Vulnerable Countries", Revue d'économie du développement, Vol. 22, p. 217-261.

Hansen, H. and F. Tarp. (2001) "Aid and growth regressions", Journal of Development Economics, 64(2), pp. 547-570.

Hoeffler, A. and V. Outram (2011) "Need, Merit, or Self-Interest-What Determines the Allocation of Aid?", Review of Development Economics, 15 (2), pp. 237-50.

IDA (2016), Additions to IDA resources: eighteens replenishment. Towards 2030: Investing in Growth, Resilience and Opportunity, available at: https://ida.worldbank.org/sites/default/files/pdfs/ida18-draft-deputies-report.pdf.

IDA (2017a) “Country Policy and Institutional Assessment”. Downloaded 171004. Available at: https://datacatalog.worldbank.org/dataset/country-policy-and-institutional-assessment IDA (2017b) "IDA Country Performance Ratings (CPR) Historical series: CPR 2006-2012. CPR 2013 and 2014", World Bank Group, Downloaded 171005. available at: http://ida.worldbank.org/financing/resource-management/ida-country-performanceratings

IDA (2019) "IDA Country Performance Ratings (CPR)", World Bank Group, available at: http://ida.worldbank.org/financing/resource-management/ida-country-performanceratings

International Committee of the Red Cross (2014) "ICRC Annual Report 2013", Geneva, Switzerland.

International Committee of the Red Cross (2013) "ICRC Annual Report 2012", Geneva, Switzerland.

International Committee of the Red Cross (2012) "ICRC Annual Report 2011", Geneva, Switzerland.

International Committee of the Red Cross (2011) "ICRC Annual Report 2010", Geneva, Switzerland. 
International Committee of the Red Cross (2010) "ICRC Annual Report 2009”, Geneva, Switzerland.

Kharas, H. and A. Rogerson (2012) "Horizon 2025: Creative destruction in the aid industry", Overseas Development Institute, July 2012.

Koch, Dirk-Jan; Axel Dreher; Rainer Thiele and Peter Nunnenkamp (2009) "Keeping a Low Profile: What Determines the Allocation of Aid by Non-Governmental Organizations?" World Development, 37(5), pp. 902-918.

Kuziemko, I. and E. Werker (2006) "How Much Is a Seat on the Security Council Worth? Foreign Aid and Bribery at the United Nations." Journal of Political Economy, 114 (5), pp. 905-30.

Llavador, H. G., and J. Roemer (2001) "An equal-opportunity approach to the allocation of international aid", Journal of Development Economics, 64(1), pp. 147-171.

Mawdsley, E., L. Savage, and K. Sung-Mi (2014), “A 'post-aid world'? Paradigm shift in foreign aid and development cooperation at the 2011 Busan High Level Forum”, The Geographical Journal, pp. 27-38.

Mekasha, T. J. and F. Tarp (2019) "A meta-analysis of aid effectiveness: revisiting the evidence", Politics and governance, 7(2), pp. 5-28.

McGillivray, M. and T. K. C. Pham (2017) "Reforming Performance-Based Aid Allocation Practice", World Development, Vol. 90, pp. 1-5.

Médecins Sans Frontières (2014) "International Financial Report 2013”, Geneva, MSF International.

Médecins Sans Frontières (2013) “International Financial Report 2012”, Geneva, MSF International.

Médecins Sans Frontières (2012) “International Financial Report 2011”, Geneva, MSF International.

Médecins Sans Frontières (2011) “International Financial Report 2010”, Geneva, MSF International.

Médecins Sans Frontières (2010) “International Financial Report 2009”, Geneva, MSF International.

OECD (2016) "Development Co-operation Report 2016: The Sustainable Development Goals as Business Opportunities", OECD Publishing, Paris, available at: http://dx.doi.org/10.1787/dcr-2016-en 
OECD-DAC (2020) "Aid (ODA) disbursements to countries and regions [DAC2a]", TABLE2A_30072020074834372.csv Downloaded 200730. Available at: https://stats.oecd.org/Index.aspx?DataSetCode=Table2A

OECD (2021) "History of DAC Lists of aid recipient countries", available at: https://www.oecd.org/development/financing-sustainable-development/developmentfinance-standards/historyofdaclistsofaidrecipientcountries.htm

Roodman, D. (2007) “The anarchy of numbers: aid, development, and cross-country empirics", World Bank Economic Review, 21(2), pp. 255-77.

Sterck, O., Roser, M. and S. Thewissen (2017) "Turning the paradigm of aid allocation on its head", CSAE Working Paper WPS/2017-03, University of Oxford, available at: https://www.csae.ox.ac.uk/materials/papers/csae-wps-2017-03.pdf

Strange, A., Cheng, M., Russell, B., Ghose, S. and B. Parks (2017) “AidData's Tracking Underreported Financial Flows (TUFF) Methodology, Version 1.3”, Williamsburg, VA: AidData at William \& Mary.

United Nations (2019a) "LDC data", Department of Economic and Social Affairs Economic Analysis, available at: https://www.un.org/development/desa/dpad/least-developedcountry-category/ldc-data-retrieval.html

United Nations (2019b) "Sustainable development goals", available at: https://www.un.org/sustainabledevelopment/.

UNDP (2016) "Human Development Index (HDI)". Downloaded 161222. Available at: http://hdr.undp.org/en/content/human-development-index-hdi

Wood, A. (2008) "Looking Ahead Optimally in Allocating Aid", World Development, 36(7), pp. 1135-1151.

World Bank (2019a) "Poverty: Overview", available at: https://www.worldbank.org/en/topic/poverty/overview

World Bank (2019b) "World Development Indicators", available at: https://datacatalog.worldbank.org/dataset/world-development-indicators.

World Bank (2019c) "Worldwide Governance Indicators", available at https://datacatalog.worldbank.org/dataset/worldwide-governanceindicators/resource/d048db01-0a66-485b-96a3-db28287b7a65 


\section{Figures and Tables}

Figure 1: Aid per capita (USD) vs. GNI (PPP) per capita (USD). Average 2009-2013.

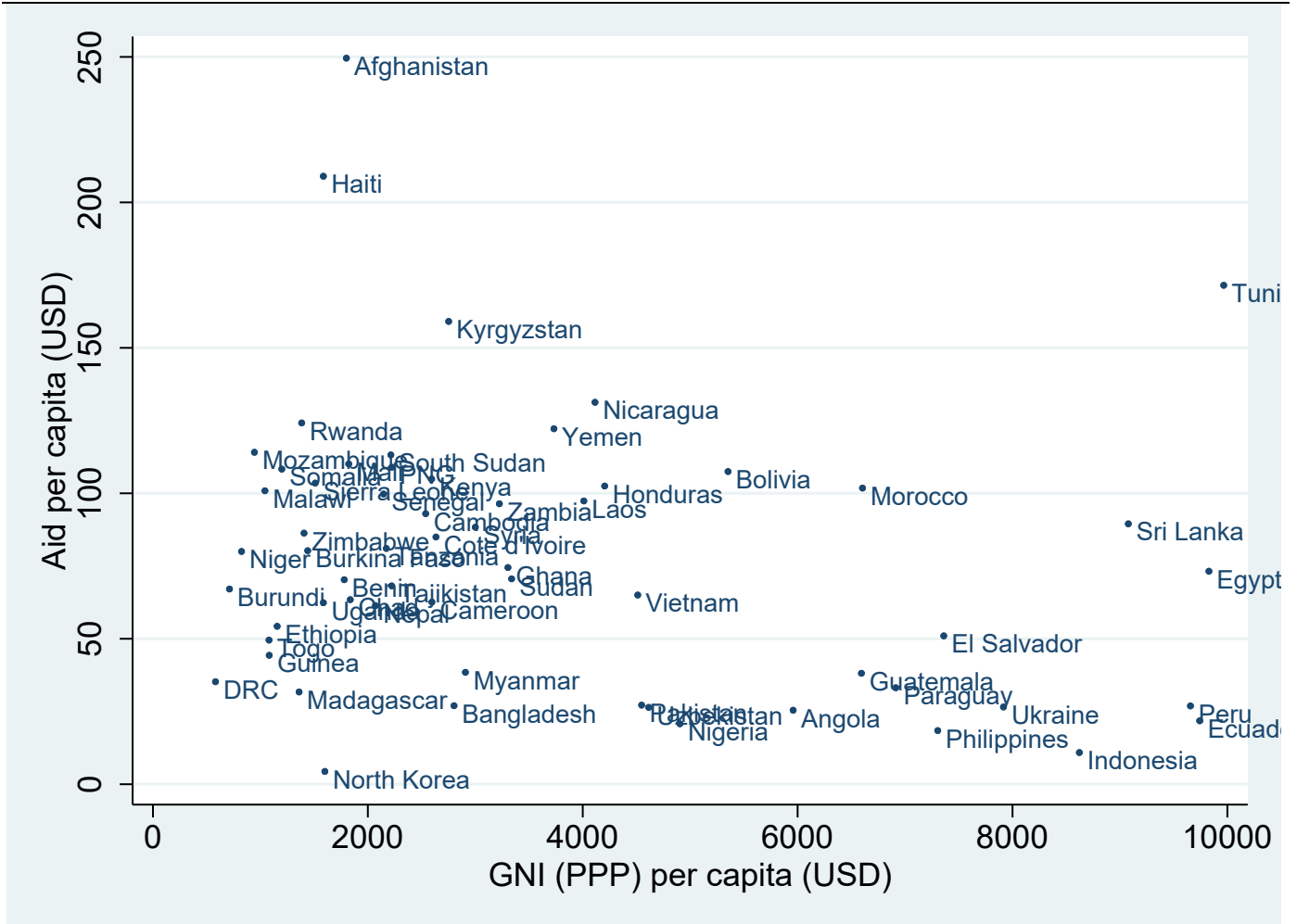

Notes: The sample excludes countries with GNI (PPP)/capita over 10,000 USD and countries with a population of less than 5 million

Figure 2: Optimal aid per capita (USD) vs. GNI (PPP) per capita USD)

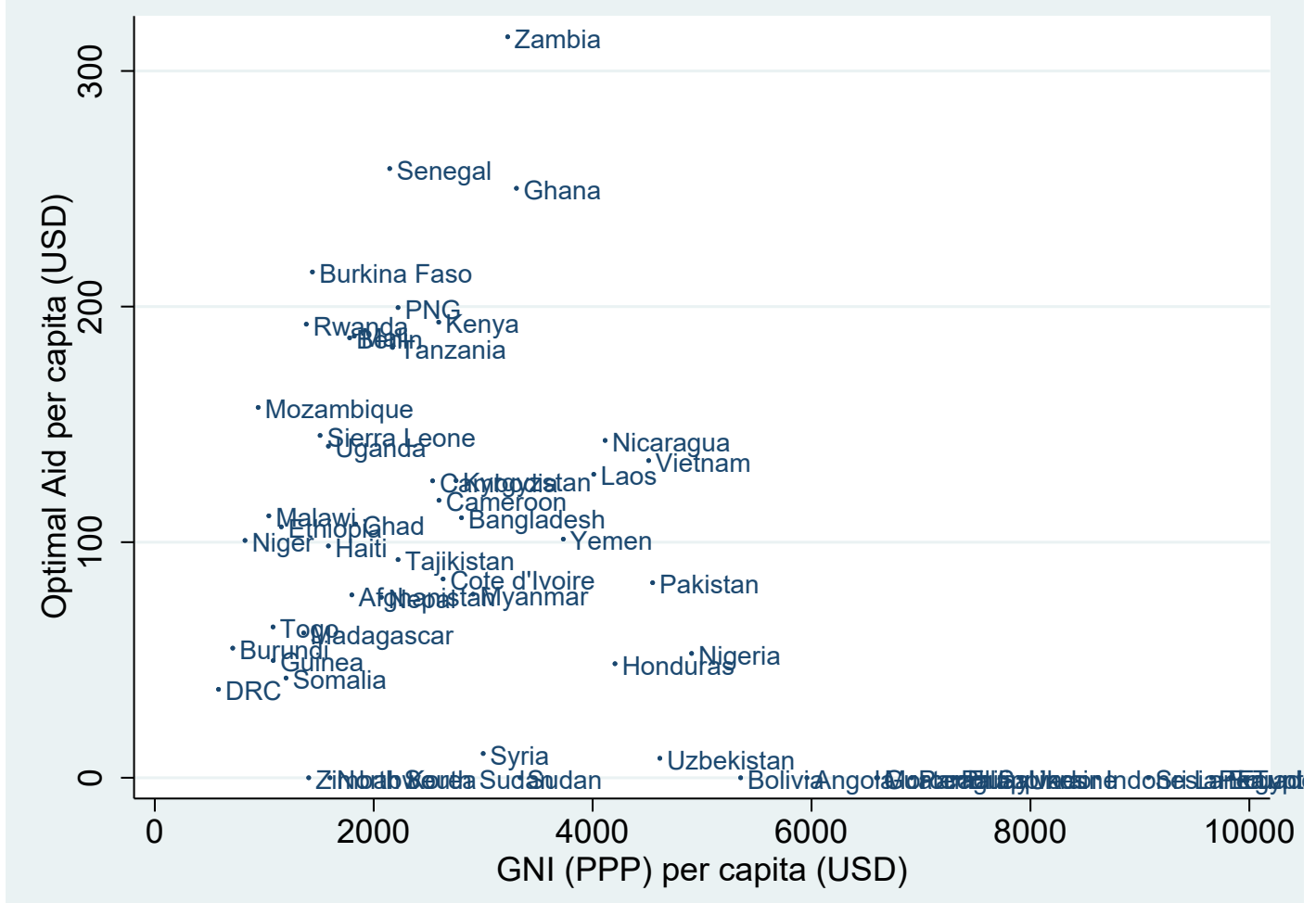

Notes: The sample excludes countries with GNI (PPP)/capita over 10,000 USD and countries with a population of less than 5 million 
Figure 3: Optimal and actual aid per capita (USD) vs. GNI (PPP) per capita (USD) for selected countries

•Afghanistan

Figure 4: Orphans and darlings

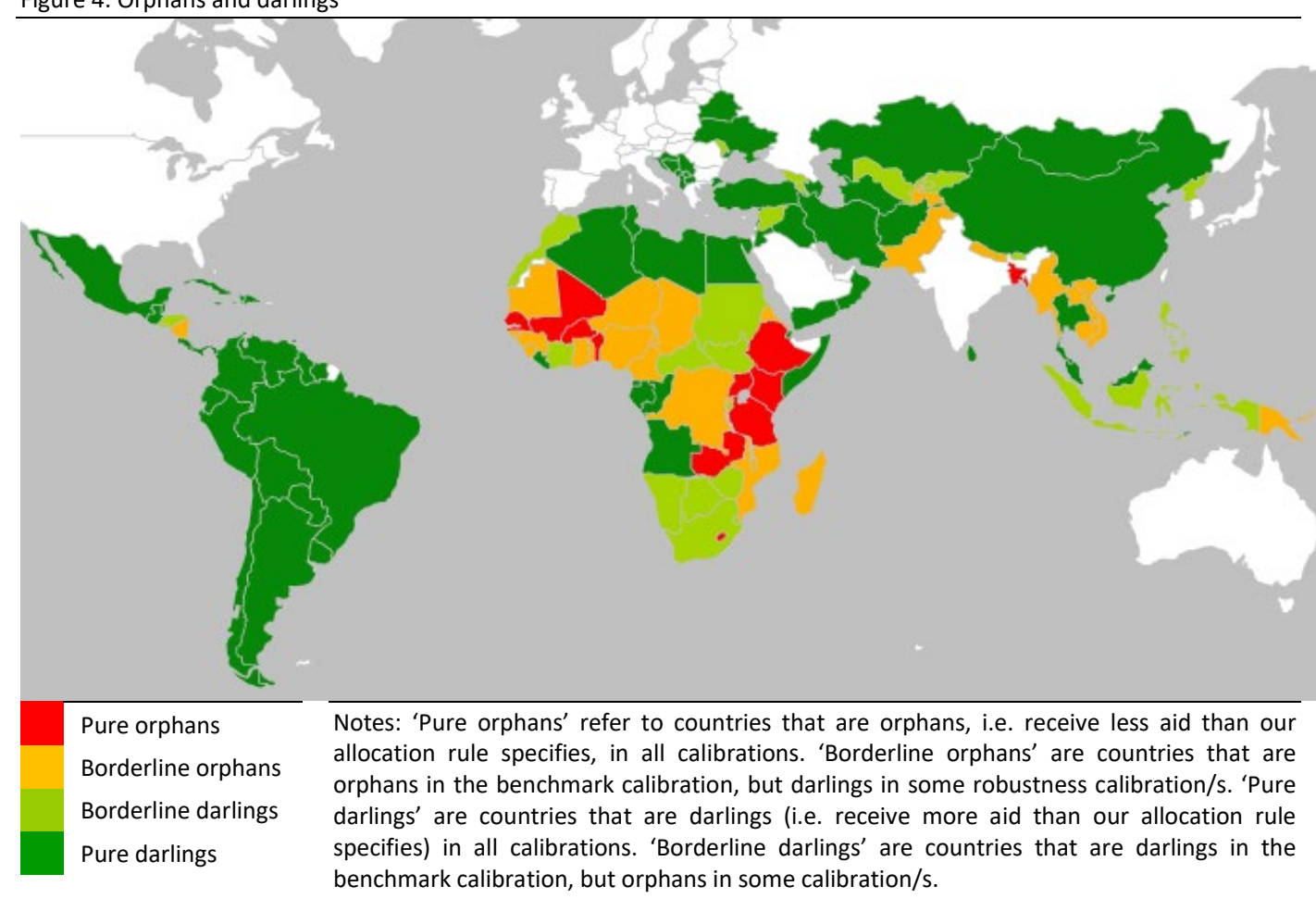


Table 1: Aggregate results, all donors

\begin{tabular}{|c|c|c|c|c|c|c|c|}
\hline & $\begin{array}{c}1 \\
\text { Actual aid } \\
\text { (mil USD) }\end{array}$ & $\begin{array}{c}2 \\
\text { Optimal aid } \\
\text { (mil USD) }\end{array}$ & $\begin{array}{c}3 \\
\text { Optimal aid } \\
\text { lower bound }\end{array}$ & $\begin{array}{c}4 \\
\text { Optimal aid } \\
\text { upper bound }\end{array}$ & $\begin{array}{c}5 \\
\text { Rec. change } \\
\text { (mil USD) }\end{array}$ & $\begin{array}{c}6 \\
\text { Rec. Change } \\
\text { lower bound }\end{array}$ & $\begin{array}{c}7 \\
\text { Rec. change } \\
\text { upper bound }\end{array}$ \\
\hline \multicolumn{8}{|l|}{ Orphans } \\
\hline Pure & 25985 & 64595 & 40017 & 88124 & 38610 & 14032 & 62139 \\
\hline Borderline & 38179 & 73107 & 9547 & 151442 & 34928 & -28632 & 113263 \\
\hline Total & 64164 & 137702 & & & 73538 & & \\
\hline \multicolumn{8}{|l|}{ Darlings } \\
\hline Pure & 60385 & 6924 & 314 & 13675 & -53461 & -60071 & -46710 \\
\hline Borderline & 24840 & 4763 & 221 & 84785 & -20077 & -24619 & 59945 \\
\hline Total & 85225 & 11687 & & & -73538 & & \\
\hline Grand Total & 149389 & 149389 & & & 0 & & \\
\hline \multicolumn{8}{|c|}{$\begin{array}{l}\text { Notes: 'Pure orphans' refer to countries that are classified as orphans, i.e. countries that receive less aid than our allocation } \\
\text { rule specifies, in all calibrations. 'Borderline orphans' are countries that are orphans in the benchmark calibration, bu } \\
\text { darlings in some robustness calibration/s. 'Pure darlings' are countries that are darlings in all calibrations. 'Borderlin } \\
\text { darlings' are countries that are darlings in the benchmark calibration, but orphans in some calibration/s. The figures in } \\
\text { Columns } 2 \text { and } 5 \text { are based on the benchmark calibration. Columns 3-4 and 6-7 are min and max values derived from the } \\
\text { sensitivity analysis. }\end{array}$} \\
\hline
\end{tabular}




\begin{tabular}{|c|c|c|c|c|c|c|c|c|c|c|c|c|c|}
\hline Country & $\begin{array}{c}1 \\
\text { population } \\
\text { mil. }\end{array}$ & $\begin{array}{c}2 \\
\text { GDP/capita } \\
\text { (USD) }\end{array}$ & $\begin{array}{c}3 \\
\text { Actual } \\
\text { aid/capita } \\
\text { (USD) }\end{array}$ & $\begin{array}{c}4 \\
\text { Actual } \\
\text { aid/GDP } \\
\% \\
\end{array}$ & $\begin{array}{c}5 \\
\text { Actual aid } \\
\text { total } \\
\text { (mil USD) }\end{array}$ & $\begin{array}{c}6 \\
\text { Optimal } \\
\text { aid/capita } \\
\text { USD }\end{array}$ & $\begin{array}{c}7 \\
\text { Optimal } \\
\text { aid/GDP } \\
\% \\
\end{array}$ & $\begin{array}{c}8 \\
\text { Optimal aid } \\
\text { total } \\
\text { (mil USD) }\end{array}$ & $\begin{array}{c}9 \\
\text { Optimal aid } \\
\text { lower } \\
\text { bound }\end{array}$ & $\begin{array}{c}10 \\
\text { Optimal aid } \\
\text { upper } \\
\text { bound }\end{array}$ & $\begin{array}{c}11 \\
\text { Rec. } \\
\text { increase } \\
\text { (mil USD) }\end{array}$ & $\begin{array}{c}12 \\
\text { Rec. } \\
\text { increase } \\
\text { lower b. }\end{array}$ & $\begin{array}{c}13 \\
\text { Rec. } \\
\text { increase } \\
\text { upper b. }\end{array}$ \\
\hline Bangladesh & 153 & 819 & 27 & 3.3 & 4141 & 110 & 13.5 & 16938 & 9707 & 24451 & 12798 & 5567 & 20311 \\
\hline Tanzania & 47 & 770 & 81 & 10.5 & 3823 & 183 & 23.7 & 8616 & 5945 & 10981 & 4793 & 2122 & 7158 \\
\hline Ethiopia & 90 & 410 & 54 & 13.2 & 4879 & 106 & 26.0 & 9573 & 6219 & 11973 & 4694 & 1340 & 7094 \\
\hline Kenya & 41 & 1079 & 105 & 9.7 & 4348 & 193 & 17.9 & 8016 & 5465 & 11677 & 3668 & 1117 & 7329 \\
\hline Zambia & 14 & 1558 & 96 & 6.2 & 1384 & 315 & 20.2 & 4517 & 2005 & 7008 & 3132 & 620 & 5623 \\
\hline Uganda & 34 & 618 & 62 & 10.1 & 2140 & 141 & 22.8 & 4826 & 3360 & 5851 & 2687 & 1220 & 3712 \\
\hline Burkina Faso & 16 & 635 & 80 & 12.6 & 1294 & 215 & 33.8 & 3460 & 1922 & 4939 & 2167 & 629 & 3646 \\
\hline Senegal & 13 & 1034 & 100 & 9.6 & 1335 & 259 & 25.0 & 3460 & 2061 & 4648 & 2125 & 727 & 3313 \\
\hline Mali & 16 & 759 & 110 & 14.5 & 1722 & 187 & 24.7 & 2932 & 1806 & 3745 & 1210 & 84 & 2023 \\
\hline Benin & 10 & 798 & 70 & 8.8 & 687 & 187 & 23.4 & 1826 & 1207 & 2270 & 1139 & 520 & 1583 \\
\hline Lesotho & 2 & 1083 & 115 & 10.6 & 234 & 211 & 19.5 & 430 & 320 & 581 & 197 & 86 & 347 \\
\hline All & 438 & & & & 25985 & & & 64595 & 40017 & 88124 & 38610 & 14032 & 62139 \\
\hline
\end{tabular}

Table 3: Actual and optimal aid to pure darlings

\begin{tabular}{|c|c|c|c|c|c|c|c|c|c|c|c|c|c|}
\hline Country & $\begin{array}{c}1 \\
\text { Population } \\
\text { (millions) }\end{array}$ & $\begin{array}{c}2 \\
\text { GDP/capita } \\
\text { (USD) }\end{array}$ & $\begin{array}{c}3 \\
\text { Actual } \\
\text { aid/capita } \\
\text { (USD) }\end{array}$ & $\begin{array}{c}4 \\
\text { Actual } \\
\text { aid / } \\
\text { GDP, \% }\end{array}$ & $\begin{array}{c}5 \\
\text { Actual aid } \\
\text { (mil USD) }\end{array}$ & $\begin{array}{c}6 \\
\text { Optimal } \\
\text { aid/capita } \\
\text { USD }\end{array}$ & $\begin{array}{c}7 \\
\text { Optimal } \\
\text { aid/GDP, \% }\end{array}$ & $\begin{array}{c}8 \\
\text { Optimal aid } \\
\text { (mil USD) }\end{array}$ & $\begin{array}{c}9 \\
\text { Optimal aid } \\
\text { lower } \\
\text { bound }\end{array}$ & $\begin{array}{c}10 \\
\text { Optimal aid } \\
\text { upper } \\
\text { bound }\end{array}$ & $\begin{array}{c}11 \\
\text { Rec. } \\
\text { decrease } \\
\text { (mil USD) }\end{array}$ & $\begin{array}{c}12 \\
\text { Rec. } \\
\text { decrease } \\
\text { lower b. }\end{array}$ & $\begin{array}{c}13 \\
\text { Rec. } \\
\text { decrease } \\
\text { upper b. }\end{array}$ \\
\hline Egypt & 84 & 2865 & 73 & 2.6 & 6142 & 0 & 0.0 & 0 & 0 & 0 & 6142 & 6142 & 6142 \\
\hline Afghanistan & 29 & 599 & 250 & 41.7 & 7206 & 78 & 13.0 & 2241 & 0 & 3531 & 4965 & 3675 & 7206 \\
\hline Turkey & 74 & 10123 & 62 & 0.6 & 4560 & 0 & 0.0 & 0 & 0 & 0 & 4560 & 4560 & 4560 \\
\hline Jordan & 7 & 4240 & 537 & 12.7 & 3624 & 0 & 0.0 & 0 & 0 & 0 & 3624 & 3624 & 3624 \\
\hline Palestine & 4 & 2549 & 619 & 24.3 & 2432 & 15 & 0.6 & 60 & 0 & 748 & 2371 & 1683 & 2432 \\
\hline Iraq & 32 & 5495 & 67 & 1.2 & 2138 & 0 & 0.0 & 0 & 0 & 0 & 2138 & 2138 & 2138 \\
\hline China & 1344 & 5429 & 1 & 0.0 & 1857 & 0 & 0.0 & 0 & 0 & 0 & 1857 & 1857 & 1857 \\
\hline Tunisia & 11 & 4212 & 171 & 4.1 & 1829 & 0 & 0.0 & 0 & 0 & 0 & 1829 & 1829 & 1829 \\
\hline Sri Lanka & 20 & 3022 & 90 & 3.0 & 1815 & 0 & 0.0 & 0 & 0 & 0 & 1815 & 1815 & 1815 \\
\hline Serbia & 7 & 5934 & 228 & 3.8 & 1648 & 0 & 0.0 & 0 & 0 & 0 & 1648 & 1648 & 1648 \\
\hline Brazil & 200 & 11373 & 7 & 0.1 & 1452 & 0 & 0.0 & 0 & 0 & 0 & 1452 & 1452 & 1452 \\
\hline Colombia & 46 & 6909 & 26 & 0.4 & 1219 & 0 & 0.0 & 0 & 0 & 0 & 1219 & 1219 & 1219 \\
\hline Ukraine & 46 & 3386 & 27 & 0.8 & 1215 & 0 & 0.0 & 0 & 0 & 0 & 1215 & 1215 & 1215 \\
\hline Haiti & 10 & 730 & 209 & 28.6 & 2120 & 98 & 13.5 & 998 & 157 & 1545 & 1122 & 575 & 1963 \\
\hline Bolivia & 10 & 2346 & 107 & 4.6 & 1083 & 0 & 0.0 & 0 & 0 & 1073 & 1083 & 10 & 1083 \\
\hline
\end{tabular}




\begin{tabular}{|c|c|c|c|c|c|c|c|c|c|c|c|c|c|}
\hline Mexico & 120 & 9234 & 7 & 0.1 & 889 & 0 & 0.0 & 0 & 0 & 0 & 889 & 889 & 889 \\
\hline Bosnia-H & 4 & 4633 & 228 & 4.9 & 873 & 0 & 0.0 & 0 & 0 & 0 & 873 & 873 & 873 \\
\hline Peru & 30 & 5593 & 27 & 0.5 & 801 & 0 & 0.0 & 0 & 0 & 0 & 801 & 801 & 801 \\
\hline Lebanon & 5 & 8612 & 157 & 1.8 & 732 & 0 & 0.0 & 0 & 0 & 0 & 732 & 732 & 732 \\
\hline Kosovo & 2 & 3544 & 364 & 10.3 & 652 & 0 & 0.0 & 0 & 0 & 403 & 652 & 249 & 652 \\
\hline Somalia & 10 & 521 & 108 & 20.8 & 1062 & 42 & 8.1 & 415 & 0 & 924 & 647 & 138 & 1062 \\
\hline Guatemala & 15 & 3060 & 38 & 1.2 & 574 & 0 & 0.0 & 0 & 0 & 0 & 574 & 574 & 574 \\
\hline Angola & 22 & 4545 & 25 & 0.6 & 558 & 0 & 0.0 & 0 & 0 & 475 & 558 & 83 & 558 \\
\hline Thailand & 67 & 5405 & 8 & 0.1 & 540 & 0 & 0.0 & 0 & 0 & 0 & 540 & 540 & 540 \\
\hline Macedonia & 2 & 4827 & 257 & 5.3 & 531 & 0 & 0.0 & 0 & 0 & 0 & 531 & 531 & 531 \\
\hline Liberia & 4 & 375 & 209 & 55.6 & 848 & 82 & 22.0 & 335 & 142 & 425 & 513 & 424 & 706 \\
\hline Yemen & 24 & 1306 & 122 & 9.4 & 2962 & 101 & 7.8 & 2456 & 0 & 2958 & 506 & 4 & 2962 \\
\hline Mongolia & 3 & 3384 & 162 & 4.8 & 447 & 0 & 0.0 & 0 & 0 & 202 & 447 & 245 & 447 \\
\hline Algeria & 37 & 4974 & 10 & 0.2 & 383 & 0 & 0.0 & 0 & 0 & 0 & 383 & 383 & 383 \\
\hline Albania & 3 & 4261 & 124 & 2.9 & 361 & 0 & 0.0 & 0 & 0 & 0 & 361 & 361 & 361 \\
\hline Dominican- $R$ & 10 & 5623 & 35 & 0.6 & 348 & 0 & 0.0 & 0 & 0 & 0 & 348 & 348 & 348 \\
\hline Mauritius & 1 & 8487 & 274 & 3.2 & 343 & 0 & 0.0 & 0 & 0 & 0 & 343 & 343 & 343 \\
\hline Congo-Brazz & 4 & 3046 & 81 & 2.7 & 339 & 0 & 0.0 & 0 & 0 & 300 & 339 & 39 & 339 \\
\hline Cabo Verde & 0 & 3560 & 677 & 19.0 & 336 & 0 & 0.0 & 0 & 0 & 253 & 336 & 83 & 336 \\
\hline Ecuador & 15 & 5178 & 22 & 0.4 & 331 & 0 & 0.0 & 0 & 0 & 0 & 331 & 331 & 331 \\
\hline Azerbaijan & 9 & 6638 & 34 & 0.5 & 312 & 0 & 0.0 & 0 & 0 & 0 & 312 & 312 & 312 \\
\hline Timor-Leste & 1 & 983 & 305 & 31.0 & 339 & 32 & 3.3 & 36 & 0 & 172 & 304 & 167 & 339 \\
\hline Jamaica & 3 & 5085 & 89 & 1.8 & 242 & 0 & 0.0 & 0 & 0 & 0 & 242 & 242 & 242 \\
\hline Mayotte & 0 & 41911 & 995 & 2.4 & 229 & 0 & 0.0 & 0 & 0 & 0 & 229 & 229 & 229 \\
\hline Guyana & 1 & 3359 & 303 & 9.0 & 229 & 0 & 0.0 & 0 & 0 & 0 & 229 & 229 & 229 \\
\hline Libya & 6 & 10218 & 36 & 0.4 & 226 & 0 & 0.0 & 0 & 0 & 0 & 226 & 226 & 226 \\
\hline Kazakhstan & 17 & 11101 & 13 & 0.1 & 220 & 0 & 0.0 & 0 & 0 & 0 & 220 & 220 & 220 \\
\hline Solomon-I & 1 & 1569 & 577 & 36.8 & 310 & 171 & 10.9 & 92 & 0 & 155 & 218 & 156 & 310 \\
\hline Paraguay & 6 & 3629 & 33 & 0.9 & 209 & 0 & 0.0 & 0 & 0 & 0 & 209 & 209 & 209 \\
\hline Fiji & 1 & 4138 & 237 & 5.7 & 206 & 0 & 0.0 & 0 & 0 & 0 & 206 & 206 & 206 \\
\hline Montenegro & 1 & 6895 & 292 & 4.2 & 181 & 0 & 0.0 & 0 & 0 & 0 & 181 & 181 & 181 \\
\hline Belarus & 9 & 6349 & 18 & 0.3 & 170 & 0 & 0.0 & 0 & 0 & 0 & 170 & 170 & 170 \\
\hline Costa Rica & 5 & 8738 & 37 & 0.4 & 170 & 0 & 0.0 & 0 & 0 & 0 & 170 & 170 & 170 \\
\hline Argentina & 42 & 12570 & 4 & 0.0 & 162 & 0 & 0.0 & 0 & 0 & 0 & 162 & 162 & 162 \\
\hline Chile & 17 & 13721 & 9 & 0.1 & 160 & 0 & 0.0 & 0 & 0 & 0 & 160 & 160 & 160 \\
\hline Cuba & 11 & 6103 & 13 & 0.2 & 149 & 0 & 0.0 & 0 & 0 & 0 & 149 & 149 & 149 \\
\hline Djibouti & 1 & 1476 & 361 & 24.5 & 304 & 188 & 12.7 & 158 & 0 & 179 & 146 & 125 & 304 \\
\hline Gabon & 2 & 10029 & 89 & 0.9 & 141 & 0 & 0.0 & 0 & 0 & 0 & 141 & 141 & 141 \\
\hline Micronesia & 0 & 2940 & 1334 & 45.4 & 138 & 0 & 0.0 & 0 & 0 & 7 & 138 & 131 & 138 \\
\hline
\end{tabular}




\begin{tabular}{|c|c|c|c|c|c|c|c|c|c|c|c|c|c|}
\hline Wallis-F & 0 & 41911 & 11174 & 26.7 & 128 & 0 & 0.0 & 0 & 0 & 0 & 128 & 128 & 128 \\
\hline Samoa & 0 & 3841 & 691 & 18.0 & 130 & 27 & 0.7 & 5 & 0 & 122 & 125 & 8 & 130 \\
\hline Iran & 75 & 6791 & 2 & 0.0 & 120 & 0 & 0.0 & 0 & 0 & 0 & 120 & 120 & 120 \\
\hline Malaysia & 29 & 9723 & 4 & 0.0 & 102 & 0 & 0.0 & 0 & 0 & 0 & 102 & 102 & 102 \\
\hline Equatorial-G & 1 & 19923 & 133 & 0.7 & 100 & 0 & 0.0 & 0 & 0 & 0 & 100 & 100 & 100 \\
\hline Marshall-I & 0 & 3285 & 1739 & 52.9 & 91 & 0 & 0.0 & 0 & 0 & 0 & 91 & 91 & 91 \\
\hline Tonga & 0 & 3875 & 825 & 21.3 & 86 & 0 & 0.0 & 0 & 0 & 33 & 86 & 53 & 86 \\
\hline Vanuatu & 0 & 3042 & 668 & 22.0 & 162 & 314 & 10.3 & 76 & 0 & 106 & 86 & 56 & 162 \\
\hline Suriname & 1 & 8696 & 145 & 1.7 & 76 & 0 & 0.0 & 0 & 0 & 0 & 76 & 76 & 76 \\
\hline Panama & 4 & 9451 & 20 & 0.2 & 75 & 0 & 0.0 & 0 & 0 & 0 & 75 & 75 & 75 \\
\hline Maldives & 0 & 6498 & 191 & 2.9 & 72 & 0 & 0.0 & 0 & 0 & 0 & 72 & 72 & 72 \\
\hline St. Helena & 0 & 40014 & 12986 & 32.5 & 65 & 0 & 0.0 & 0 & 0 & 0 & 65 & 65 & 65 \\
\hline Uruguay & 3 & 13499 & 18 & 0.1 & 60 & 0 & 0.0 & 0 & 0 & 0 & 60 & 60 & 60 \\
\hline Montserrat & 0 & 40014 & 10399 & 26.0 & 52 & 0 & 0.0 & 0 & 0 & 0 & 52 & 52 & 52 \\
\hline Dominica & 0 & 6931 & 705 & 10.2 & 50 & 0 & 0.0 & 0 & 0 & 0 & 50 & 50 & 50 \\
\hline Seychelles & 0 & 12248 & 560 & 4.6 & 50 & 0 & 0.0 & 0 & 0 & 0 & 50 & 50 & 50 \\
\hline Belize & 0 & 4503 & 149 & 3.3 & 49 & 0 & 0.0 & 0 & 0 & 0 & 49 & 49 & 49 \\
\hline Venezuela & 29 & 12181 & 2 & 0.0 & 48 & 0 & 0.0 & 0 & 0 & 0 & 48 & 48 & 48 \\
\hline Turkmenistan & 5 & 5708 & 9 & 0.2 & 47 & 0 & 0.0 & 0 & 0 & 0 & 47 & 47 & 47 \\
\hline Kiribati & 0 & 1515 & 666 & 44.0 & 70 & 229 & 15.1 & 24 & 0 & 28 & 46 & 42 & 70 \\
\hline Sao Tome-P & 0 & 1366 & 404 & 29.6 & 71 & 154 & 11.3 & 27 & 15 & 36 & 44 & 35 & 56 \\
\hline Palau & 0 & 9819 & 1767 & 18.0 & 36 & 0 & 0.0 & 0 & 0 & 0 & 36 & 36 & 36 \\
\hline Tuvalu & 0 & 3584 & 3514 & 98.1 & 35 & 0 & 0.0 & 0 & 0 & 0 & 35 & 35 & 35 \\
\hline Nauru & 0 & 11332 & 3235 & 28.6 & 33 & 0 & 0.0 & 0 & 0 & 0 & 33 & 33 & 33 \\
\hline St. Lucia & 0 & 7116 & 164 & 2.3 & 29 & 0 & 0.0 & 0 & 0 & 0 & 29 & 29 & 29 \\
\hline Grenada & 0 & 7542 & 274 & 3.6 & 29 & 0 & 0.0 & 0 & 0 & 0 & 29 & 29 & 29 \\
\hline Cook Islands & 0 & 36663 & 1486 & 4.1 & 25 & 0 & 0.0 & 0 & 0 & 0 & 25 & 25 & 25 \\
\hline Croatia & 4 & 13804 & 6 & 0.0 & 24 & 0 & 0.0 & 0 & 0 & 0 & 24 & 24 & 24 \\
\hline St. Kitts-N & 0 & 13763 & 449 & 3.3 & 24 & 0 & 0.0 & 0 & 0 & 0 & 24 & 24 & 24 \\
\hline St. Vincent-G & 0 & 6304 & 209 & 3.3 & 23 & 0 & 0.0 & 0 & 0 & 0 & 23 & 23 & 23 \\
\hline Antigua-B & 0 & 13336 & 228 & 1.7 & 20 & 0 & 0.0 & 0 & 0 & 0 & 20 & 20 & 20 \\
\hline Niue & 0 & 36663 & 11944 & 32.6 & 19 & 0 & 0.0 & 0 & 0 & 0 & 19 & 19 & 19 \\
\hline Tokelau & 0 & 36663 & 11507 & 31.4 & 17 & 0 & 0.0 & 0 & 0 & 0 & 17 & 17 & 17 \\
\hline Anguilla & 0 & 40014 & 518 & 1.3 & 8 & 0 & 0.0 & 0 & 0 & 0 & 8 & 8 & 8 \\
\hline Oman & 3 & 20030 & 2 & 0.0 & 8 & 0 & 0.0 & 0 & 0 & 0 & 8 & 8 & 8 \\
\hline Trinidad-T & 1 & 17435 & 1 & 0.0 & 2 & 0 & 0.0 & 0 & 0 & 0 & 2 & 2 & 2 \\
\hline Barbados & 0 & 15686 & 4 & 0.0 & 1 & 0 & 0.0 & 0 & 0 & 0 & 1 & 1 & 1 \\
\hline All & 2593 & & & & 60385 & & & 6924 & 314 & 13675 & 53461 & 46710 & 60071 \\
\hline
\end{tabular}


Table 4 : Aid volumes and poverty reducing efficiency, by donor groups

\begin{tabular}{|c|c|c|c|c|c|c|}
\hline & $\begin{array}{c}1 \\
\text { Volume (milj \$) }\end{array}$ & $\begin{array}{c}2 \\
\text { Poverty reducing } \\
\text { efficiency per \$ }\end{array}$ & $\begin{array}{c}3 \\
\text { Lower bound }\end{array}$ & $\begin{array}{c}4 \\
\text { Upper bound }\end{array}$ & $\begin{array}{c}5 \\
\text { Proportion of } \\
\text { poverty reduction (\%) } \\
\end{array}$ & $\begin{array}{c}6 \\
\text { Average poverty } \\
\text { in recipient countries } \\
\end{array}$ \\
\hline All Donors Total & 149389 & 100 & 100 & 100 & 100,0 & 23.8 \\
\hline Old aid (total) & 122279 & 104,3 & 102,9 & 105,6 & 85,4 & 24.7 \\
\hline Bilateral DAC donors & 68090 & 90,5 & 89,4 & 94,9 & 41,2 & 24.0 \\
\hline EC & 19007 & 66,9 & 58,1 & 69,7 & 8,5 & 15.7 \\
\hline UN & 2905 & 139,7 & 113 & 161 & 2,7 & 30.1 \\
\hline WB & 14255 & 194,1 & 177,7 & 203,2 & 18,5 & 35.3 \\
\hline IMF & 1325 & 111,2 & 92,1 & 173,8 & 1,0 & 33.8 \\
\hline Regional development banks & 7561 & 125 & 115,1 & 138,7 & 6,3 & 27.2 \\
\hline Other multilateral donors (excl. Vertical Funds) & 2243 & 62,2 & 56,2 & 67,5 & 0,9 & 14.7 \\
\hline NGOs & 6893 & 133,4 & 102,7 & 157 & 6,2 & 31.2 \\
\hline New aid (total) & 27110 & 80,5 & 74,7 & 87 & 14,6 & 20.0 \\
\hline Bilateral non-DAC donors & 21382 & 63,5 & 55 & 73,8 & 9,1 & 15.9 \\
\hline New global actors & 5729 & 144,1 & 134,6 & 162,1 & 5,5 & 35.2 \\
\hline Vertical funds & 5033 & 140,7 & 125,6 & 155 & 4,7 & 34.7 \\
\hline Bill and Melinda Gates Fund & 696 & 168,9 & 134,5 & 223,7 & 0,8 & 38.9 \\
\hline \multicolumn{7}{|l|}{ New Financial flows } \\
\hline OOF & 82860 & & & & & 10.2 \\
\hline Personal remittances & 264463 & & & & & 14.0 \\
\hline 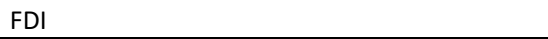 & 580858 & & & & & 10.2 \\
\hline
\end{tabular}


Table 5: Allocation across orphan and darling countries, in per capita terms as well as the percentage share of the financial flow going to the group in question

\begin{tabular}{|c|c|c|c|c|c|c|c|c|c|}
\hline & & \multirow{2}{*}{$\begin{array}{l}\text { All aid } \\
\text { Total }\end{array}$} & \multicolumn{2}{|c|}{ Old aid } & \multicolumn{2}{|c|}{ New aid } & \multicolumn{3}{|c|}{ New Financial Flows } \\
\hline & & & $\begin{array}{c}\text { Traditional aid } \\
\text { (Bi- \& Multilateral) }\end{array}$ & $\mathrm{NGOs}$ & $\begin{array}{l}\text { Bilateral } \\
\text { Non-DAC }\end{array}$ & New actors & $\mathrm{OOF}$ & FDI & $\begin{array}{c}\text { Personal } \\
\text { remittances }\end{array}$ \\
\hline \multirow[t]{2}{*}{ Pure orphans } & USD per capita & 59,4 & 49,3 & 2,9 & 4,0 & 3,1 & 9,2 & 16,8 & 41,3 \\
\hline & Share (\%) & 17,4 & 18,8 & 18,7 & 8,2 & 23,6 & 4,9 & 1,3 & 6,8 \\
\hline \multirow[t]{2}{*}{ Borderline orphans } & USD per capita & 47,8 & 38,5 & 2,1 & 4,1 & 3,1 & 15,0 & 40,0 & 64,4 \\
\hline & Share (\%) & 25,6 & 26,8 & 24,4 & 15,4 & 42,6 & 14,4 & 5,5 & 19,4 \\
\hline \multirow[t]{2}{*}{ Borderline darlings } & USD per capita & 39,4 & 29,1 & 2,3 & 6,4 & 1,5 & 21,6 & 59,0 & 95,6 \\
\hline & Share (\%) & 16,6 & 16,0 & 21,2 & 18,9 & 16,9 & 16,4 & 6,4 & 22,8 \\
\hline \multirow[t]{2}{*}{ Pure darlings } & USD per capita & 23,3 & 17,2 & 0,9 & 4,7 & 0,4 & 20,5 & 194,6 & 52,0 \\
\hline & Share (\%) & 40,5 & 38,9 & 35,7 & 57,5 & 16,9 & 64,3 & 86,8 & 50,9 \\
\hline \multirow{2}{*}{ Total } & USD per capita & 33,5 & 25,9 & 1,5 & 4,8 & 1,3 & 18,6 & 130,3 & 59,3 \\
\hline & Share (\%) & 100,0 & 100,0 & 100,0 & 100,0 & 100,0 & 100,0 & 100,0 & 100,0 \\
\hline
\end{tabular}




\section{Appendix A: Tables referred to in the text}

Table A1: Variable descriptions

\begin{tabular}{|c|c|c|}
\hline Variable & Description & Source \\
\hline \multicolumn{3}{|l|}{ Old aid } \\
\hline DAC bilateral aid & ODA from Bilateral DAC donors, yearly average 2009-2013 in USD. & AidData (2017a) \\
\hline Multilateral aid & $\begin{array}{l}\text { ODA from EC, UN, WB, IMF, Regional Banks, and other multilateral } \\
\text { donors (except Vertical funds), yearly average 2009-2013 in USD. }\end{array}$ & AidData (2017a) \\
\hline \multicolumn{3}{|l|}{ Aid from NGOs } \\
\hline NGO data from Koch et al. & Aid from NGOs in 2005 & Koch et al. (2009) \\
\hline \multirow[t]{2}{*}{ NGO data from MSF \& ICRS } & $\begin{array}{l}\text { Aid from Doctors without borders (MSF) the International Red Cross } \\
\text { (ICRC). }\end{array}$ & $\begin{array}{l}\text { Médecins Sans Frontières (2010, } \\
\text { 2011, 2012, 2013, 2014). }\end{array}$ \\
\hline & Yearly averages $2009-2013$ in USD. & $\begin{array}{l}\text { International Committee of the } \\
\text { Red Cross }(2010,2011,2012 \\
2013,2014)\end{array}$ \\
\hline \multicolumn{3}{|l|}{ New aid } \\
\hline \multirow[t]{5}{*}{ Non-DAC bilateral aid } & $\begin{array}{l}\text { ODA from Brazil, Chile, Colombia, Estonia, India, Kuwait, Latvia, } \\
\text { Liechtenstein, Lithuania, Monaco, South Africa, Taiwan, Thailand, and } \\
\text { United Arab Emirates. We also include Czech Republic, Hungary, } \\
\text { Iceland, Poland, Slovak Republic, and Slovenia since they were not } \\
\text { DAC-members most of the period 2009-13. }\end{array}$ & $\begin{array}{l}\text { AidData (2014a, 2014b, 2017a, } \\
\text { 2017b) }\end{array}$ \\
\hline & $\begin{array}{l}\text { 'Tracking Under-reported Financial Flows (TUFF) data on 'ODA-like' } \\
\text { flows from China, Qatar and Saudi Arabia. }\end{array}$ & \\
\hline & Yearly average $2009-2013$ in USD. & \\
\hline & ODA from Bulgaria, Croatia, Israel, Kazakhstan, Russia, and Turkey & OECD-DAC (2020) \\
\hline & Yearly average $2009-2013$ in USD. & \\
\hline New global actors & $\begin{array}{l}\text { Aid from the Bill and Melinda Gates Foundation (BMGF), the Global } \\
\text { Fund to Fight AIDS, Tuberculosis and Malaria (GFATM), the Global } \\
\text { Alliance for Vaccines and Immunization (GAVI), and the Global } \\
\text { Environment Facility (GEF). }\end{array}$ & AidData (2017a) \\
\hline & Yearly average $2009-2013$ in USD. & \\
\hline \multicolumn{3}{|l|}{ Non-aid flows } \\
\hline \multirow[t]{3}{*}{ Other Official Flows, OOF } & $\begin{array}{l}\text { Transactions by the official sector which do not meet (all) the } \\
\text { conditions for eligibility as ODA (being concessional, having a grant } \\
\text { element of at least } 25 \text { percent, and a development objective), }\end{array}$ & $\begin{array}{l}\text { AidData (2014a, 2014b, 2017a, } \\
\text { 2017b) }\end{array}$ \\
\hline & We use 2013 in USD, since data is missing for the other years. & \\
\hline & $\begin{array}{l}\text { We use Commitments and Current USD (just as in the aid data from the } \\
\text { Aiddata } 3.1 \text { dataset) }\end{array}$ & \\
\hline FDI & Foreign direct investment, net inflows (BoP, current US\$). & World Bank (2019b) \\
\hline Remittances & Personal remittances, received (current US\$) & World Bank (2019b) \\
\hline \multicolumn{3}{|l|}{ Other variables } \\
\hline GDP per capita & GDP per capita in current USD & World Bank (2019b) \\
\hline GNI (PPP) per capita & GNI per capita (current international \$, PPP-adjusted) & World Bank (2019b) \\
\hline \multirow[t]{4}{*}{ Poverty } & $\begin{array}{l}\text { Poverty index based on } \mathrm{GNI} / \text { capita (PPP): } h_{i}^{0}=k y_{P P P, i}^{-\alpha} \text { Where } k \text { is a } \\
\text { constant, } \alpha \text { is elasticity of poverty with respect to income, and } y_{P P P, i} \text { is } \\
\mathrm{GNI} / \text { cap (PPP) in country } i \text {. }\end{array}$ & World Bank (2019b) \\
\hline & Headcount ratio at $\$ 1.90$ a day (PPP), \% of population & \\
\hline & Headcount ratio at $\$ 3.10$ a day (PPP), \% of population & \\
\hline & Average $2009-2013$ & \\
\hline Population, total & Population & World Bank (2019b) \\
\hline
\end{tabular}


Country Performance Rating (CPR)

Augmented Country Performance Rating (ACPR)

\section{Help variables:}

WGI (Worldwide Governance Indicators)

Economic Vulnerability Index (EVI) and Human Assets Index (HAI)

Human Development Index

Life expectancy at birth

Poverty headcount ratio at national poverty lines (\% of population)

CPIA (Country Policy and Institutional Assessment)
Country performance rating of the International Development

IDA (2017b)

Association, World Bank. CPR $=0.24 C P I A_{A}$ to $C+0.68 C P I A_{D}+$ $0.08 P P R$, where the country policy and institutional assessment (CPIA) index is based on indicators focusing on $(A)$ macroeconomic management, (B) structural policies, (C) social policies, and (D) public sector management and institutions, and PPR is the IDA portfolio performance rating.

We do not do these calculations by hand. CPR is already available, as its own dataset, for all the countries in the CPIA dataset.

Average 2009-2013

Augmented Country Performance Rating is a weighted average of the World Bank CPR and the Economic Vulnerability Index (EVI) and Human Assets Index (HAI) of the UN.

Weighting as suggested by Guillaumont, GuillaumontJenneney and Wagner (2017: 32).

World Bank (2019c)

Used to construct ACPR.

United Nations (2019a)

EVI and HAI are from 2012 due to data limitations.

If HAI \& EVI is missing, then we predict ACPR from HDI. If also HDI is missing, we use ACPR = CPR.

UNDP (2016)

Average 2010-2013 due to data limitations

In years. Used to predict poverty when Poverty 1.90 and/or poverty 3.10 is missing.

World Bank (2019b)

Used to predict poverty when Poverty 1.90 and/or poverty 3.10 is missing.

Used to find calibrations of the interaction of Policy and aid.
IDA (2017a) 
Table A2 Descriptive statistics for pure orphan countries

\begin{tabular}{|c|c|c|c|c|c|c|c|c|c|c|c|}
\hline Country & $\begin{array}{l}\text { Population } \\
\text { (milj) }\end{array}$ & $\begin{array}{c}\text { GDP } \\
\text { per capita } \\
\text { (USD) }\end{array}$ & Poverty index & CPR & ACPR & $\begin{array}{c}\text { Aid } \\
\text { per capita } \\
\text { (USD) }\end{array}$ & $\begin{array}{l}\text { Aid / GDP } \\
\text { (\%) }\end{array}$ & $\begin{array}{l}\text { Aid total } \\
\text { (milj. USD) }\end{array}$ & $\begin{array}{c}\text { OOF } \\
\text { per capita } \\
\text { (USD) }\end{array}$ & $\begin{array}{c}\text { FDI } \\
\text { per capita } \\
\text { (USD) } \\
\end{array}$ & $\begin{array}{l}\text { Remittances } \\
\text { per capita } \\
\text { (USD) }\end{array}$ \\
\hline Bangladesh & 153 & 819 & 18.2 & 3.1 & 3.1 & 27 & 3.3 & 4141 & 4.0 & 9.9 & 80.1 \\
\hline Benin & 10 & 798 & 36.0 & 3.4 & 3.4 & 70 & 8.8 & 687 & 6.1 & 17.1 & 18.3 \\
\hline Burkina Faso & 16 & 635 & 49.4 & 3.7 & 3.7 & 80 & 12.6 & 1294 & 7.7 & 13.1 & 11.9 \\
\hline Ethiopia & 90 & 410 & 68.7 & 3.3 & 3.4 & 54 & 13.2 & 4879 & 20.3 & 5.3 & 5.3 \\
\hline Kenya & 41 & 1079 & 20.4 & 3.5 & 3.3 & 105 & 9.7 & 4348 & 7.0 & 4.7 & 23.0 \\
\hline Lesotho & 2 & 1083 & 18.0 & 3.4 & 3.3 & 115 & 10.6 & 234 & 0.0 & 28.5 & 277.6 \\
\hline Mali & 16 & 759 & 34.7 & 3.3 & 3.4 & 110 & 14.5 & 1722 & 9.3 & 29.2 & 43.9 \\
\hline Senegal & 13 & 1034 & 27.2 & 3.6 & 3.5 & 100 & 9.6 & 1335 & 10.1 & 22.8 & 114.7 \\
\hline Tanzania & 47 & 770 & 26.7 & 3.5 & 3.4 & 81 & 10.5 & 3823 & 4.3 & 33.4 & 6.6 \\
\hline Uganda & 34 & 618 & 42.8 & 3.4 & 3.3 & 62 & 10.1 & 2140 & 8.5 & 26.7 & 24.6 \\
\hline Zambia & 14 & 1558 & 14.8 & 3.3 & 3.5 & 96 & 6.2 & 1384 & 25.7 & 102.6 & 3.6 \\
\hline
\end{tabular}


Table A3: Descriptive statistics for borderline orphan countries

\begin{tabular}{|c|c|c|c|c|c|c|c|c|c|c|c|}
\hline Country & $\begin{array}{l}\text { Population } \\
\text { (milj.) }\end{array}$ & $\begin{array}{c}\text { GDP } \\
\text { per capita } \\
\text { (USD) }\end{array}$ & Poverty index & CPR & ACPR & $\begin{array}{c}\text { Aid } \\
\text { per capita } \\
\text { (USD) }\end{array}$ & $\begin{array}{l}\text { Aid / GDP } \\
\text { (\%) }\end{array}$ & $\begin{array}{l}\text { Aid total } \\
\text { (milj. USD) }\end{array}$ & $\begin{array}{c}\text { OOF } \\
\text { per capita } \\
\text { (USD) }\end{array}$ & $\begin{array}{l}\text { FDI per capita } \\
\text { (USD) }\end{array}$ & $\begin{array}{l}\text { Remittances } \\
\text { per capita } \\
\text { (USD) }\end{array}$ \\
\hline Cambodia & 15 & 874 & 21.1 & 3.0 & 3.1 & 93 & 10.6 & 1358 & 53.3 & 66.1 & 11.0 \\
\hline Cameroon & 21 & 1225 & 20.4 & 3.0 & 3.0 & 63 & 5.1 & 1323 & 11.4 & 28.5 & 9.2 \\
\hline Chad & 12 & 929 & 34.3 & 2.4 & 3.0 & 63 & 6.8 & 781 & 1.7 & 33.6 & 0.1 \\
\hline DRC & 68 & 350 & 100.0 & 2.5 & 2.9 & 35 & 10.1 & 2400 & 1.2 & -2.4 & 0.6 \\
\hline Eritrea & 5 & 467 & 56.3 & 2.5 & 3.0 & 23 & 4.9 & 108 & 0.0 & 13.1 & 0.7 \\
\hline Gambia & 2 & 524 & 43.5 & 3.2 & 3.4 & 128 & 24.4 & 224 & 12.1 & 21.0 & 71.4 \\
\hline Ghana & 25 & 1495 & 14.2 & 3.7 & 3.3 & 74 & 5.0 & 1857 & 13.4 & 117.7 & 51.4 \\
\hline Guinea & 11 & 463 & 75.9 & 2.7 & 2.9 & 44 & 9.6 & 502 & 6.0 & 19.6 & 5.7 \\
\hline Guinea-Bissau & 2 & 572 & 54.8 & 2.6 & 3.0 & 62 & 10.8 & 103 & 0.0 & 11.5 & 30.6 \\
\hline Laos & 6 & 1309 & 10.6 & 3.2 & 3.1 & 97 & 7.4 & 620 & 316.5 & 50.9 & 9.7 \\
\hline Madagascar & 22 & 439 & 53.9 & 3.0 & 3.0 & 32 & 7.2 & 688 & 0.1 & 38.9 & 19.4 \\
\hline Malawi & 15 & 431 & 80.3 & 3.3 & 3.4 & 101 & 23.4 & 1538 & 3.0 & 24.4 & 1.7 \\
\hline Mauritania & 4 & 1300 & 13.9 & 3.1 & 3.2 & 175 & 13.4 & 643 & 19.7 & 175.2 & 20.9 \\
\hline Mozambique & 25 & 515 & 93.1 & 3.5 & 3.6 & 114 & 22.2 & 2856 & 1.7 & 145.3 & 5.5 \\
\hline Myanmar & 52 & 1264 & 17.2 & 2.8 & 2.9 & 38 & 3.0 & 2005 & 0.8 & 31.0 & 8.5 \\
\hline Nepal & 27 & 631 & 28.7 & 3.1 & 3.0 & 61 & 9.7 & 1669 & 0.5 & 2.8 & 154.8 \\
\hline Nicaragua & 6 & 1657 & 10.2 & 3.4 & 3.1 & 131 & 7.9 & 762 & 25.1 & 118.6 & 158.6 \\
\hline Niger & 17 & 377 & 100.0 & 3.3 & 3.4 & 80 & 21.2 & 1358 & 2.8 & 47.9 & 8.2 \\
\hline Nigeria & 164 & 2328 & 7.9 & 3.1 & 3.1 & 21 & 0.9 & 3405 & 6.7 & 44.0 & 122.1 \\
\hline Pakistan & 174 & 1165 & 8.8 & 3.1 & 3.0 & 27 & 2.3 & 4724 & 25.0 & 9.1 & 68.3 \\
\hline PNG & 7 & 1746 & 25.8 & 3.0 & 3.0 & 109 & 6.2 & 763 & 12.3 & 2.6 & 1.5 \\
\hline Rwanda & 11 & 607 & 52.5 & 3.7 & 3.7 & 124 & 20.4 & 1311 & 2.0 & 13.0 & 12.9 \\
\hline Sierra Leone & 6 & 568 & 46.0 & 3.2 & 3.4 & 103 & 18.2 & 612 & 12.7 & 82.9 & 9.2 \\
\hline Tajikistan & 8 & 854 & 25.8 & 3.1 & 2.9 & 68 & 8.0 & 529 & 9.0 & 5.5 & 385.6 \\
\hline Togo & 7 & 548 & 76.1 & 2.8 & 2.9 & 50 & 9.0 & 325 & 6.5 & 37.0 & 50.5 \\
\hline Vietnam & 88 & 1554 & 8.9 & 3.6 & 3.2 & 65 & 4.2 & 5715 & 25.5 & 91.7 & 86.8 \\
\hline
\end{tabular}




\begin{tabular}{|c|c|c|c|c|c|c|c|c|c|c|c|}
\hline Country & $\begin{array}{l}\text { Population } \\
\text { (milj.) }\end{array}$ & $\begin{array}{c}\text { GDP } \\
\text { per capita } \\
\text { (USD) }\end{array}$ & Poverty & CPR & ACPR & $\begin{array}{l}\text { Aid per } \\
\text { capita } \\
\text { (USD) }\end{array}$ & $\begin{array}{l}\text { Aid / GDP } \\
\text { (\%) }\end{array}$ & $\begin{array}{l}\text { Aid total } \\
\text { (milj. USD) }\end{array}$ & $\begin{array}{c}\text { OOF } \\
\text { per capita } \\
\text { (USD) }\end{array}$ & $\begin{array}{c}\text { FDI } \\
\text { per capita } \\
\text { (USD) }\end{array}$ & $\begin{array}{l}\text { Remittances } \\
\text { per capita } \\
\text { (USD) }\end{array}$ \\
\hline Armenia & 3 & 3348 & 4.4 & 3.9 & 3.4 & 158 & 4.7 & 469 & 74.1 & 189.6 & 606.3 \\
\hline Bhutan & 1 & 2262 & 5.4 & 3.9 & 3.7 & 502 & 22.2 & 367 & 0.0 & 54.4 & 14.6 \\
\hline Botswana & 2 & 6511 & 1.7 & 4.1 & 3.7 & 80 & 1.2 & 168 & 78.9 & 338.1 & 10.7 \\
\hline Burundi & 10 & 230 & 100.0 & 2.9 & 3.3 & 67 & 29.2 & 657 & 0.0 & 0.2 & 4.2 \\
\hline CAR & 5 & 436 & 100.0 & 2.6 & 3.0 & 77 & 17.7 & 349 & 0.0 & 9.4 & 0.0 \\
\hline Comoros & 1 & 767 & 54.5 & 2.6 & 2.9 & 145 & 18.9 & 104 & 0.0 & 16.7 & 145.6 \\
\hline Cote d'Ivoire & 21 & 1286 & 20.0 & 2.8 & 2.9 & 85 & 6.6 & 1753 & 15.9 & 17.4 & 17.8 \\
\hline El Salvador & 6 & 3744 & 4.3 & 3.8 & 3.3 & 51 & 1.4 & 309 & 58.6 & 35.3 & 606.7 \\
\hline Georgia & 4 & 3563 & 4.5 & 4.1 & 3.5 & 242 & 6.8 & 938 & 100.8 & 180.9 & 390.0 \\
\hline Honduras & 8 & 2232 & 9.9 & 3.3 & 3.0 & 102 & 4.6 & 781 & 14.5 & 109.2 & 365.5 \\
\hline Indonesia & 245 & 3274 & 3.4 & 3.5 & 3.0 & 11 & 0.3 & 2664 & 14.9 & 69.6 & 29.0 \\
\hline Kyrgyzstan & 6 & 1067 & 18.7 & 3.2 & 3.0 & 159 & 14.9 & 880 & 31.0 & 81.3 & 298.7 \\
\hline Moldova & 4 & 1884 & 9.0 & 3.6 & 3.2 & 165 & 8.7 & 587 & 51.6 & 71.2 & 479.7 \\
\hline Morocco & 33 & 2979 & 5.0 & 3.6 & 3.2 & 102 & 3.4 & 3314 & 84.2 & 73.3 & 204.8 \\
\hline Namibia & 2 & 5181 & 3.5 & 3.8 & 3.4 & 185 & 3.6 & 416 & 130.2 & 175.4 & 6.1 \\
\hline North Korea & 25 & 1137 & 42.2 & 2.1 & 2.3 & 4 & 0.4 & 108 & 0.1 & 3.7 & \\
\hline Philippines & 95 & 2349 & 4.3 & 3.7 & 3.2 & 18 & 0.8 & 1742 & 18.8 & 25.6 & 245.1 \\
\hline South Africa & 52 & 7172 & 2.1 & 4.0 & 3.4 & 30 & 0.4 & 1527 & 16.4 & 109.8 & 20.0 \\
\hline South Sudan & 11 & 1327 & 25.9 & 2.1 & 2.5 & 113 & 8.5 & 1191 & 5.5 & -30.0 & 0.2 \\
\hline Sudan & 37 & 1518 & 14.0 & 2.3 & 2.6 & 71 & 4.7 & 2606 & 15.0 & 51.6 & 26.5 \\
\hline Swaziland & 1 & 3473 & 4.4 & 3.3 & 3.2 & 100 & 2.9 & 121 & 0.0 & 68.3 & 40.8 \\
\hline Syria & 20 & 1217 & 16.4 & 3.0 & 2.7 & 88 & 7.3 & 1786 & 0.1 & 99.9 & 77.6 \\
\hline Uzbekistan & 29 & 1540 & 8.6 & 3.0 & 2.9 & 26 & 1.7 & 769 & 55.9 & 36.4 & 148.2 \\
\hline Zimbabwe & 14 & 759 & 51.2 & 2.1 & 2.4 & 86 & 11.4 & 1233 & 9.4 & 20.4 & 119.6 \\
\hline
\end{tabular}


Table A5: Descriptive statistics for pure darling countries

\begin{tabular}{|c|c|c|c|c|c|c|c|c|c|c|c|}
\hline Country & $\begin{array}{l}\text { Population } \\
\text { (milj.) }\end{array}$ & $\begin{array}{l}\text { GDP per } \\
\text { capita } \\
\text { (USD) } \\
\end{array}$ & Poverty & CPR & ACPR & $\begin{array}{l}\text { Aid per capita } \\
\text { (USD) }\end{array}$ & $\begin{array}{c}\text { Aid / GDP } \\
\text { (\%) }\end{array}$ & $\begin{array}{l}\text { Aid total } \\
\text { (milj. USD) }\end{array}$ & $\begin{array}{c}\text { OOF } \\
\text { per capita } \\
\text { (USD) }\end{array}$ & $\begin{array}{l}\text { FDI per capita } \\
\text { (USD) }\end{array}$ & $\begin{array}{c}\text { Remittances } \\
\text { per capita } \\
\text { (USD) }\end{array}$ \\
\hline Afghanistan & 29 & 599 & 35.4 & 2.6 & 3.0 & 250 & 41.7 & 7206 & 0.5 & 2.8 & 8.6 \\
\hline Albania & 3 & 4261 & 2.8 & 3.6 & 3.2 & 124 & 2.9 & 361 & 135.1 & 388.9 & 393.4 \\
\hline Algeria & 37 & 4974 & 1.8 & 3.1 & 2.8 & 10 & 0.2 & 383 & 0.0 & 58.8 & 5.3 \\
\hline Angola & 22 & 4545 & 5.9 & 2.5 & 3.0 & 25 & 0.6 & 558 & 48.4 & -164.5 & 0.2 \\
\hline Anguilla & 0 & 40014 & 0.4 & 4.8 & 4.8 & 518 & 1.3 & 8 & 0.0 & & \\
\hline Antigua-B & 0 & 13336 & 1.0 & 4.1 & 3.5 & 228 & 1.7 & 20 & 113.4 & 1148.4 & 234.0 \\
\hline Argentina & 42 & 12570 & 0.9 & 3.4 & 2.9 & 4 & 0.0 & 162 & 39.3 & 246.4 & 14.7 \\
\hline Azerbaijan & 9 & 6638 & 1.5 & 3.3 & 2.9 & 34 & 0.5 & 312 & 96.6 & 406.4 & 180.5 \\
\hline Barbados & 0 & 15686 & 1.5 & 4.5 & 3.7 & 4 & 0.0 & 1 & 1.2 & 1385.7 & 408.5 \\
\hline Belarus & 9 & 6349 & 1.4 & 2.9 & 2.6 & 18 & 0.3 & 170 & 175.9 & 231.7 & 89.4 \\
\hline Belize & 0 & 4503 & 4.3 & 3.4 & 3.2 & 149 & 3.3 & 49 & 0.0 & 356.8 & 232.4 \\
\hline Bolivia & 10 & 2346 & 6.9 & 3.3 & 3.1 & 107 & 4.6 & 1083 & 20.8 & 93.5 & 106.6 \\
\hline Bosnia-H & 4 & 4633 & 2.9 & 3.4 & 3.1 & 228 & 4.9 & 873 & 99.8 & 93.1 & 506.3 \\
\hline Brazil & 200 & 11373 & 1.6 & 3.7 & 3.1 & 7 & 0.1 & 1452 & 37.0 & 375.9 & 14.7 \\
\hline Cabo Verde & 0 & 3560 & 6.1 & 4.0 & 3.5 & 677 & 19.0 & 336 & 206.4 & 227.3 & 321.9 \\
\hline Chile & 17 & 13721 & 1.1 & 4.7 & 3.9 & 9 & 0.1 & 160 & 42.4 & 1161.2 & 6.0 \\
\hline China & 1344 & 5429 & 2.6 & 3.7 & 3.1 & 1 & 0.0 & 1857 & 4.9 & 176.6 & 11.1 \\
\hline Colombia & 46 & 6909 & 2.3 & 3.8 & 3.2 & 26 & 0.4 & 1219 & 36.3 & 260.2 & 89.3 \\
\hline Congo-Brazz & 4 & 3046 & 9.8 & 2.7 & 2.8 & 81 & 2.7 & 339 & 3.0 & 452.6 & 12.9 \\
\hline Cook Islands & 0 & 36663 & 0.5 & 2.9 & 2.9 & 1486 & 4.1 & 25 & 352.9 & & \\
\hline Costa Rica & 5 & 8738 & 1.9 & 4.0 & 3.4 & 37 & 0.4 & 170 & 135.9 & 516.3 & 118.4 \\
\hline Croatia & 4 & 13804 & 1.0 & 4.1 & 3.4 & 6 & 0.0 & 24 & 0.0 & 390.0 & 468.4 \\
\hline Cuba & 11 & 6103 & 1.1 & 3.1 & 2.8 & 13 & 0.2 & 149 & 0.0 & & \\
\hline Djibouti & 1 & 1476 & 18.2 & 2.9 & 3.1 & 361 & 24.5 & 304 & 148.2 & 144.5 & 39.5 \\
\hline Dominica & 0 & 6931 & 2.8 & 3.8 & 3.3 & 705 & 10.2 & 50 & 195.9 & 341.6 & 321.1 \\
\hline Dominican- $R$ & 10 & 5623 & 2.4 & 3.4 & 3.0 & 35 & 0.6 & 348 & 68.6 & 206.0 & 404.8 \\
\hline Ecuador & 15 & 5178 & 2.8 & 3.1 & 2.8 & 22 & 0.4 & 331 & 143.7 & 31.8 & 170.7 \\
\hline Egypt & 84 & 2865 & 2.8 & 3.3 & 2.9 & 73 & 2.6 & 6142 & 40.0 & 46.7 & 169.2 \\
\hline Equatorial-G & 1 & 19923 & 1.0 & 2.5 & 2.8 & 133 & 0.7 & 100 & 154.4 & 2145.3 & 0.2 \\
\hline Fiji & 1 & 4138 & 4.2 & 3.1 & 2.9 & 237 & 5.7 & 206 & 29.3 & 309.0 & 207.6 \\
\hline Gabon & 2 & 10029 & 1.5 & 3.1 & 3.0 & 89 & 0.9 & 141 & 65.5 & 427.3 & 14.3 \\
\hline Grenada & 0 & 7542 & 2.5 & 3.6 & 3.2 & 274 & 3.6 & 29 & 0.0 & 593.4 & 274.1 \\
\hline Guatemala & 15 & 3060 & 5.0 & 3.3 & 3.0 & 38 & 1.2 & 574 & 13.4 & 70.4 & 308.1 \\
\hline
\end{tabular}




\begin{tabular}{|c|c|c|c|c|c|c|c|c|c|c|c|}
\hline Guyana & 1 & 3359 & 5.6 & 3.1 & 2.9 & 303 & 9.0 & 229 & 0.0 & 287.7 & 486.7 \\
\hline Haiti & 10 & 730 & 42.8 & 2.7 & 3.0 & 209 & 28.6 & 2120 & 1.2 & 13.2 & 153.7 \\
\hline Iran & 75 & 6791 & 1.2 & 3.0 & 2.8 & 2 & 0.0 & 120 & 4.6 & 49.5 & 15.9 \\
\hline Iraq & 32 & 5495 & 1.7 & 2.8 & 2.9 & 67 & 1.2 & 2138 & 19.8 & 85.2 & 6.8 \\
\hline Jamaica & 3 & 5085 & 3.6 & 3.8 & 3.3 & 89 & 1.8 & 242 & 122.2 & 137.2 & 767.7 \\
\hline Jordan & 7 & 4240 & 2.6 & 3.8 & 3.2 & 537 & 12.7 & 3624 & 50.5 & 263.9 & 591.4 \\
\hline Kazakhstan & 17 & 11101 & 1.0 & 3.4 & 2.9 & 13 & 0.1 & 220 & 139.5 & 713.6 & 11.9 \\
\hline Kiribati & 0 & 1515 & 21.0 & 3.1 & 3.2 & 666 & 44.0 & 70 & 5.7 & -6.1 & 150.0 \\
\hline Kosovo & 2 & 3544 & 3.5 & 3.4 & 3.4 & 364 & 10.3 & 652 & 27.4 & 232.1 & 598.2 \\
\hline Lebanon & 5 & 8612 & 1.4 & 3.5 & 3.0 & 157 & 1.8 & 732 & 32.2 & 790.4 & 1527.5 \\
\hline Liberia & 4 & 375 & 100.0 & 2.9 & 3.3 & 209 & 55.6 & 848 & 4.3 & 159.3 & 64.7 \\
\hline Libya & 6 & 10218 & 0.8 & 2.7 & 2.4 & 36 & 0.4 & 226 & 9.6 & 210.9 & 2.6 \\
\hline Macedonia & 2 & 4827 & 2.1 & 3.7 & 3.2 & 257 & 5.3 & 531 & 0.0 & 175.2 & 191.1 \\
\hline Malaysia & 29 & 9723 & 0.9 & 4.3 & 3.6 & 4 & 0.0 & 102 & 1.1 & 324.2 & 43.1 \\
\hline Maldives & 0 & 6498 & 2.9 & 3.4 & 3.2 & 191 & 2.9 & 72 & 173.6 & 736.9 & 9.1 \\
\hline Marshall-I & 0 & 3285 & 9.7 & 2.8 & 2.8 & 1739 & 52.9 & 91 & 0.0 & 208.7 & 440.5 \\
\hline Mauritius & 1 & 8487 & 1.3 & 4.4 & 3.6 & 274 & 3.2 & 343 & 275.1 & 319.6 & 0.5 \\
\hline Mayotte & 0 & 41911 & 0.4 & 4.7 & 4.7 & 995 & 2.4 & 229 & 0.0 & & \\
\hline Mexico & 120 & 9234 & 1.4 & 3.9 & 3.3 & 7 & 0.1 & 889 & 21.8 & 223.2 & 190.4 \\
\hline Micronesia & 0 & 2940 & 12.9 & 2.8 & 2.7 & 1334 & 45.4 & 138 & 46.5 & 7.7 & 188.5 \\
\hline Mongolia & 3 & 3384 & 3.6 & 3.4 & 3.2 & 162 & 4.8 & 447 & 96.5 & 987.1 & 95.7 \\
\hline Montenegro & 1 & 6895 & 1.6 & 3.7 & 3.1 & 292 & 4.2 & 181 & 218.9 & 1267.5 & 549.5 \\
\hline Montserrat & 0 & 40014 & 0.4 & 4.9 & 4.9 & 10399 & 26.0 & 52 & 0.0 & & \\
\hline Nauru & 0 & 11332 & 1.6 & 3.1 & 3.1 & 3235 & 28.6 & 33 & 0.0 & 27.6 & 412.0 \\
\hline Niue & 0 & 36663 & 0.5 & 2.9 & 2.9 & 11944 & 32.6 & 19 & 0.0 & & \\
\hline Oman & 3 & 20030 & 0.3 & 4.0 & 3.4 & 2 & 0.0 & 8 & 0.0 & 379.3 & 11.9 \\
\hline Palau & 0 & 9819 & 2.0 & 3.1 & 2.8 & 1767 & 18.0 & 36 & 0.0 & 518.8 & 96.6 \\
\hline Palestine & 4 & 2549 & 8.2 & 3.4 & 3.1 & 619 & 24.3 & 2432 & 0.0 & 49.4 & 308.3 \\
\hline Panama & 4 & 9451 & 1.4 & 3.9 & 3.3 & 20 & 0.2 & 75 & 185.6 & 851.9 & 107.4 \\
\hline Paraguay & 6 & 3629 & 4.7 & 3.2 & 3.0 & 33 & 0.9 & 209 & 57.1 & 52.7 & 82.1 \\
\hline Peru & 30 & 5593 & 2.8 & 3.7 & 3.2 & 27 & 0.5 & 801 & 20.4 & 294.0 & 88.2 \\
\hline Samoa & 0 & 3841 & 7.0 & 4.1 & 3.6 & 691 & 18.0 & 130 & 4.5 & 59.3 & 810.6 \\
\hline Sao Tome-P & 0 & 1366 & 18.0 & 3.2 & 3.1 & 404 & 29.6 & 71 & 0.0 & 144.8 & 55.1 \\
\hline Serbia & 7 & 5934 & 2.0 & 3.6 & 3.1 & 228 & 3.8 & 1648 & 105.4 & 355.9 & 560.6 \\
\hline Seychelles & 0 & 12248 & 0.9 & 3.7 & 3.3 & 560 & 4.6 & 50 & 414.9 & 2579.1 & 201.7 \\
\hline Solomon-I & 1 & 1569 & 42.5 & 2.8 & 3.0 & 577 & 36.8 & 310 & 63.9 & 153.2 & 31.6 \\
\hline Somalia & 10 & 521 & 65.1 & 2.0 & 2.8 & 108 & 20.8 & 1062 & 0.0 & 17.8 & 2.2 \\
\hline
\end{tabular}




\begin{tabular}{|c|c|c|c|c|c|c|c|c|c|c|c|}
\hline Sri Lanka & 20 & 3022 & 3.1 & 3.4 & 3.0 & 90 & 3.0 & 1815 & 73.5 & 36.6 & 247.0 \\
\hline St. Helena & 0 & 40014 & 0.4 & 4.9 & 4.9 & 12986 & 32.5 & 65 & 0.0 & & \\
\hline St. Kitts-N & 0 & 13763 & 1.0 & 4.2 & 3.7 & 449 & 3.3 & 24 & 0.0 & 2112.5 & 879.7 \\
\hline St. Lucia & 0 & 7116 & 2.6 & 3.9 & 3.3 & 164 & 2.3 & 29 & 0.0 & 584.7 & 163.5 \\
\hline St. Vincent-G & 0 & 6304 & 2.7 & 3.8 & 3.3 & 209 & 3.3 & 23 & 0.0 & 979.2 & 274.5 \\
\hline Suriname & 1 & 8696 & 1.5 & 3.5 & 3.4 & 145 & 1.7 & 76 & 277.1 & 61.3 & 10.6 \\
\hline Thailand & 67 & 5405 & 1.8 & 3.9 & 3.3 & 8 & 0.1 & 540 & 1.8 & 156.3 & 63.7 \\
\hline Timor-Leste & 1 & 983 & 4.9 & 2.7 & 3.0 & 305 & 31.0 & 339 & 50.8 & 40.2 & 97.2 \\
\hline Tokelau & 0 & 36663 & 0.5 & 5.1 & 5.1 & 11507 & 31.4 & 17 & 0.0 & & \\
\hline Tonga & 0 & 3875 & 7.5 & 3.6 & 3.3 & 825 & 21.3 & 86 & 3.1 & 41.4 & 894.6 \\
\hline Trinidad-T & 1 & 17435 & 0.6 & 4.0 & 3.4 & 1 & 0.0 & 2 & 22.5 & 1037.1 & 86.7 \\
\hline Tunisia & 11 & 4212 & 2.7 & 3.7 & 3.1 & 171 & 4.1 & 1829 & 47.5 & 110.7 & 198.6 \\
\hline Turkey & 74 & 10123 & 1.2 & 4.0 & 3.3 & 62 & 0.6 & 4560 & 53.3 & 161.7 & 25.3 \\
\hline Turkmenistan & 5 & 5708 & 2.5 & 2.4 & 2.4 & 9 & 0.2 & 47 & 319.3 & 721.9 & 7.1 \\
\hline Tuvalu & 0 & 3584 & 7.1 & 3.0 & 2.9 & 3514 & 98.1 & 35 & 0.0 & 76.2 & 431.2 \\
\hline Ukraine & 46 & 3386 & 3.8 & 3.2 & 2.8 & 27 & 0.8 & 1215 & 40.8 & 136.0 & 168.0 \\
\hline Uruguay & 3 & 13499 & 1.2 & 4.1 & 3.5 & 18 & 0.1 & 60 & 218.8 & 714.4 & 35.5 \\
\hline Vanuatu & 0 & 3042 & 18.0 & 3.4 & 3.2 & 668 & 22.0 & 162 & 7.3 & 228.3 & 75.0 \\
\hline Venezuela & 29 & 12181 & 1.2 & 2.7 & 2.5 & 2 & 0.0 & 48 & 65.4 & 91.3 & 4.4 \\
\hline Wallis-F & 0 & 41911 & 0.4 & 4.7 & 4.7 & 11174 & 26.7 & 128 & 0.0 & & \\
\hline Yemen & 24 & 1306 & 11.8 & 2.9 & 3.0 & 122 & 9.4 & 2962 & 16.8 & -2.9 & 89.0 \\
\hline
\end{tabular}


Table A6: Actual and optimal aid to borderline orphans

\begin{tabular}{|c|c|c|c|c|c|c|c|c|c|c|c|c|c|}
\hline Country & $\begin{array}{c}1 \\
\text { Population } \\
\text { (millions) }\end{array}$ & $\begin{array}{c}2 \\
\text { GDP/capita } \\
\text { (USD) }\end{array}$ & $\begin{array}{c}3 \\
\text { Actual } \\
\text { aid/capita } \\
\text { (USD) }\end{array}$ & $\begin{array}{c}4 \\
\text { Actual aid / } \\
\text { GDP, \% }\end{array}$ & $\begin{array}{c}5 \\
\text { Actual aid } \\
\text { (mil USD) }\end{array}$ & $\begin{array}{c}6 \\
\text { Optimal } \\
\text { aid/capita } \\
\text { USD }\end{array}$ & $\begin{array}{c}7 \\
\text { Optimal } \\
\text { aid/GDP, \% }\end{array}$ & $\begin{array}{c}8 \\
\text { Optimal aid } \\
\text { (mil USD) }\end{array}$ & $\begin{array}{c}9 \\
\begin{array}{c}\text { Optimal aid } \\
\text { lower } \\
\text { bound }\end{array} \\
\end{array}$ & $\begin{array}{c}10 \\
\text { Optimal aid } \\
\text { upper } \\
\text { bound }\end{array}$ & $\begin{array}{c}11 \\
\text { Rec. } \\
\text { decrease } \\
\text { (mil USD) }\end{array}$ & $\begin{array}{c}12 \\
\text { Rec. } \\
\text { decrease } \\
\text { lower b. }\end{array}$ & $\begin{array}{c}13 \\
\text { Rec. } \\
\text { decrease } \\
\text { upper b. }\end{array}$ \\
\hline Pakistan & 174 & 1165 & 27 & 2.3 & 4724 & 83 & 7.1 & 14383 & 0 & 20577 & 9659 & -4724 & 15852 \\
\hline Vietnam & 88 & 1554 & 65 & 4.2 & 5715 & 135 & 8.7 & 11831 & 0 & 22479 & 6117 & -5715 & 16764 \\
\hline Nigeria & 164 & 2328 & 21 & 0.9 & 3405 & 53 & 2.3 & 8647 & 0 & 49705 & 5243 & -3405 & 46301 \\
\hline Ghana & 25 & 1495 & 74 & 5 & 1857 & 250 & 16.7 & 6239 & 0 & 8917 & 4382 & -1857 & 7060 \\
\hline Myanmar & 52 & 1264 & 38 & 3 & 2005 & 78 & 6.2 & 4065 & 0 & 7590 & 2060 & -2005 & 5585 \\
\hline Cameroon & 21 & 1225 & 63 & 5.1 & 1323 & 118 & 9.6 & 2489 & 349 & 3829 & 1166 & -974 & 2507 \\
\hline Mozambique & 25 & 515 & 114 & 22.2 & 2856 & 157 & 30.5 & 3936 & 2316 & 5308 & 1079 & -540 & 2451 \\
\hline Rwanda & 11 & 607 & 124 & 20.4 & 1311 & 193 & 31.7 & 2032 & 1182 & 2825 & 721 & -129 & 1514 \\
\hline Madagascar & 22 & 439 & 32 & 7.2 & 688 & 61 & 14 & 1333 & 591 & 2263 & 645 & -96 & 1575 \\
\hline PNG & 7 & 1746 & 109 & 6.2 & 763 & 200 & 11.4 & 1397 & 547 & 1838 & 635 & -216 & 1075 \\
\hline Chad & 12 & 929 & 63 & 6.8 & 781 & 108 & 11.6 & 1326 & 0 & 2141 & 545 & -781 & 1360 \\
\hline Cambodia & 15 & 874 & 93 & 10.6 & 1358 & 126 & 14.4 & 1840 & 651 & 2373 & 483 & -707 & 1015 \\
\hline Nepal & 27 & 631 & 61 & 9.7 & 1669 & 77 & 12.2 & 2084 & 598 & 3844 & 414 & -1072 & 2175 \\
\hline Niger & 17 & 377 & 80 & 21.2 & 1358 & 101 & 26.7 & 1711 & 1021 & 2154 & 352 & -338 & 796 \\
\hline Sierra Leone & 6 & 568 & 103 & 18.2 & 612 & 145 & 25.6 & 859 & 424 & 1087 & 247 & -187 & 475 \\
\hline Laos & 6 & 1309 & 97 & 7.4 & 620 & 129 & 9.8 & 820 & 464 & 1237 & 200 & -156 & 618 \\
\hline Tajikistan & 8 & 854 & 68 & 8 & 529 & 93 & 10.8 & 718 & 0 & 1331 & 190 & -529 & 802 \\
\hline Eritrea & 5 & 467 & 23 & 4.9 & 108 & 59 & 12.7 & 279 & 0 & 462 & 171 & -108 & 354 \\
\hline DRC & 68 & 350 & 35 & 10.1 & 2400 & 38 & 10.7 & 2557 & 0 & 4828 & 157 & -2400 & 2428 \\
\hline Malawi & 15 & 431 & 101 & 23.4 & 1538 & 111 & 25.8 & 1695 & 1078 & 2109 & 157 & -459 & 572 \\
\hline Togo & 7 & 548 & 50 & 9 & 325 & 64 & 11.7 & 421 & 106 & 800 & 95 & -220 & 475 \\
\hline Nicaragua & 6 & 1657 & 131 & 7.9 & 762 & 143 & 8.6 & 831 & 0 & 1338 & 69 & -762 & 576 \\
\hline Guinea & 11 & 463 & 44 & 9.6 & 502 & 50 & 10.7 & 564 & 93 & 1133 & 62 & -409 & 631 \\
\hline Guinea-Bissau & 2 & 572 & 62 & 10.8 & 103 & 85 & 14.9 & 143 & 8 & 215 & 40 & -95 & 111 \\
\hline Mauritania & 4 & 1300 & 175 & 13.4 & 643 & 184 & 14.2 & 679 & 0 & 776 & 35 & -643 & 132 \\
\hline Gambia & 2 & 524 & 128 & 24.4 & 224 & 129 & 24.7 & 227 & 119 & 281 & 3 & -105 & 57 \\
\hline All & 798 & & & & 38179 & & & 73107 & 9547 & 151442 & 34928 & -28632 & 113263 \\
\hline
\end{tabular}


Table A7: Actual and optimal aid to Borderline Darlings

\begin{tabular}{|c|c|c|c|c|c|c|c|c|c|c|c|c|c|}
\hline Country & $\begin{array}{c}1 \\
\text { Population } \\
\text { (millions) }\end{array}$ & $\begin{array}{c}2 \\
\text { GDP/capita } \\
\text { (USD) }\end{array}$ & $\begin{array}{c}3 \\
\text { Actual } \\
\text { aid/capita } \\
\text { (USD) }\end{array}$ & $\begin{array}{c}4 \\
\text { Actual aid / } \\
\text { GDP, \% }\end{array}$ & $\begin{array}{c}5 \\
\text { Actual aid } \\
\text { (mil USD) }\end{array}$ & $\begin{array}{c}6 \\
\text { Optimal } \\
\text { aid/capita } \\
\text { USD }\end{array}$ & $\begin{array}{c}7 \\
\text { Optimal } \\
\text { aid/GDP, \% }\end{array}$ & $\begin{array}{c}8 \\
\begin{array}{c}\text { Optimal aid } \\
\text { (mil USD) }\end{array}\end{array}$ & $\begin{array}{c}9 \\
\text { Optimal aid } \\
\text { lower } \\
\text { bound }\end{array}$ & $\begin{array}{c}10 \\
\text { Optimal aid } \\
\text { upper } \\
\text { bound }\end{array}$ & $\begin{array}{c}11 \\
\text { Rec. } \\
\text { decrease } \\
\text { (mil USD) }\end{array}$ & $\begin{array}{c}12 \\
\text { Rec. } \\
\text { decrease } \\
\text { lower b. }\end{array}$ & $\begin{array}{c}13 \\
\text { Rec. } \\
\text { decrease } \\
\text { upper b. }\end{array}$ \\
\hline Morocco & 33 & 2979 & 102 & 3.4 & 3314 & 0 & 0 & 0 & 0 & 5044 & 3314 & -1730 & 3314 \\
\hline Indonesia & 245 & 3274 & 11 & 0.3 & 2664 & 0 & 0 & 0 & 0 & 23318 & 2664 & -20654 & 2664 \\
\hline Sudan & 37 & 1518 & 71 & 4.7 & 2606 & 0 & 0 & 0 & 0 & 3036 & 2606 & -430 & 2606 \\
\hline Philippines & 95 & 2349 & 18 & 0.8 & 1742 & 0 & 0 & 0 & 0 & 16482 & 1742 & -14740 & 1742 \\
\hline Syria & 20 & 1217 & 88 & 7.3 & 1786 & 10 & 0.8 & 208 & 0 & 3004 & 1578 & -1218 & 1786 \\
\hline South Africa & 52 & 7172 & 30 & 0.4 & 1527 & 0 & 0 & 0 & 0 & 8760 & 1527 & -7232 & 1527 \\
\hline Zimbabwe & 14 & 759 & 86 & 11.4 & 1233 & 0 & 0 & 0 & 0 & 1519 & 1233 & -287 & 1233 \\
\hline South Sudan & 11 & 1327 & 113 & 8.5 & 1191 & 0 & 0 & 0 & 0 & 1209 & 1191 & -18 & 1191 \\
\hline Georgia & 4 & 3563 & 242 & 6.8 & 938 & 0 & 0 & 0 & 0 & 1807 & 938 & -869 & 938 \\
\hline Uzbekistan & 29 & 1540 & 26 & 1.7 & 769 & 8 & 0.5 & 241 & 0 & 2783 & 528 & -2014 & 769 \\
\hline Armenia & 3 & 3348 & 158 & 4.7 & 469 & 0 & 0 & 0 & 0 & 852 & 469 & -383 & 469 \\
\hline Namibia & 2 & 5181 & 185 & 3.6 & 416 & 0 & 0 & 0 & 0 & 1332 & 416 & -917 & 416 \\
\hline Honduras & 8 & 2232 & 102 & 4.6 & 781 & 48 & 2.2 & 369 & 0 & 1596 & 412 & -815 & 781 \\
\hline El Salvador & 6 & 3744 & 51 & 1.4 & 309 & 0 & 0 & 0 & 0 & 1212 & 309 & -903 & 309 \\
\hline Bhutan & 1 & 2262 & 502 & 22.2 & 367 & 178 & 7.9 & 130 & 0 & 408 & 237 & -41 & 367 \\
\hline Kyrgyzstan & 6 & 1067 & 159 & 14.9 & 880 & 126 & 11.8 & 698 & 0 & 1100 & 182 & -220 & 880 \\
\hline Botswana & 2 & 6511 & 80 & 1.2 & 168 & 0 & 0 & 0 & 0 & 1846 & 168 & -1679 & 168 \\
\hline Swaziland & 1 & 3473 & 100 & 2.9 & 121 & 0 & 0 & 0 & 0 & 465 & 121 & -344 & 121 \\
\hline Burundi & 10 & 230 & 67 & 29.2 & 657 & 55 & 23.9 & 539 & 198 & 657 & 118 & 0 & 459 \\
\hline North Korea & 25 & 1137 & 4 & 0.4 & 108 & 0 & 0 & 0 & 0 & 3464 & 108 & -3355 & 108 \\
\hline CAR & 5 & 436 & 77 & 17.7 & 349 & 55 & 12.6 & 249 & 24 & 423 & 101 & -73 & 326 \\
\hline Moldova & 4 & 1884 & 165 & 8.7 & 587 & 150 & 7.9 & 533 & 0 & 923 & 54 & -336 & 587 \\
\hline Comoros & 1 & 767 & 145 & 18.9 & 104 & 77 & 10.1 & 55 & 0 & 104 & 48 & -1 & 104 \\
\hline Cote d'Ivoire & 21 & 1286 & 85 & 6.6 & 1753 & 84 & 6.6 & 1741 & 0 & 3442 & 12 & -1689 & 1753 \\
\hline All & 631 & & & & 24840 & & & 4763 & 221 & 84785 & 20077 & -59945 & 24619 \\
\hline
\end{tabular}




\begin{tabular}{|c|c|c|c|c|c|}
\hline & $\begin{array}{c}1 \\
\text { Volume (milj } \\
\$ \text { ) } \\
\end{array}$ & $\begin{array}{c}2 \\
\text { Poverty } \\
\text { reducing } \\
\text { efficiency per } \$ \\
\end{array}$ & $\begin{array}{c} \\
\text { Lower } \\
\text { bound } \\
\end{array}$ & $\begin{array}{c}4 \\
\text { Upper } \\
\text { bound } \\
\end{array}$ & $\begin{array}{c}5 \\
\text { Proportion of } \\
\text { poverty reduction } \\
(\%) \\
\end{array}$ \\
\hline All Donors Total & 149389 & 100.0 & 100.0 & 100.0 & 100.00 \\
\hline Old aid & 122279 & 104.3 & 102.9 & 105.6 & 85.38 \\
\hline DAC bilateral donors & 68090 & 90.5 & 89.4 & 94.9 & 41.23 \\
\hline Australia & 2706 & 29.1 & 22.3 & 66.3 & 0.53 \\
\hline Austria & 281 & 85.5 & 65.8 & 106.3 & 0.16 \\
\hline Belgium & 872 & 351.5 & 128.2 & 512.1 & 2.05 \\
\hline Canada & 2046 & 166.3 & 140.4 & 189.5 & 2.28 \\
\hline Denmark & 1209 & 142.4 & 112.9 & 190.1 & 1.15 \\
\hline Finland & 528 & 135.6 & 124.2 & 155.7 & 0.48 \\
\hline France & 6331 & 53.1 & 49.0 & 67.9 & 2.25 \\
\hline Germany & 6876 & 69.1 & 64.2 & 72.9 & 3.18 \\
\hline Greece & 64 & 20.9 & 10.1 & 31.5 & 0.01 \\
\hline Ireland & 430 & 281.3 & 204.9 & 334.5 & 0.81 \\
\hline Italy & 543 & 111.6 & 85.9 & 123.7 & 0.41 \\
\hline Japan & 12445 & 50.0 & 42.1 & 84.0 & 4.17 \\
\hline Korea & 1625 & 89.6 & 81.0 & 117.6 & 0.98 \\
\hline Luxembourg & 198 & 148.2 & 127.7 & 189.6 & 0.20 \\
\hline Netherlands & 1309 & 191.8 & 150.8 & 225.2 & 1.68 \\
\hline New Zealand & 243 & 10.7 & 6.3 & 30.7 & 0.02 \\
\hline Norway & 1841 & 128.9 & 105.2 & 141.7 & 1.59 \\
\hline Portugal & 358 & 223.4 & 108.4 & 329.4 & 0.54 \\
\hline Spain & 1469 & 77.8 & 61.6 & 83.8 & 0.76 \\
\hline Sweden & 1455 & 141.3 & 122.1 & 164.1 & 1.38 \\
\hline Switzerland & 1063 & 108.4 & 95.5 & 120.8 & 0.77 \\
\hline United Kingdom & 3186 & 154.1 & 139.3 & 174.5 & 3.29 \\
\hline United States & 21012 & 89.3 & 87.2 & 93.1 & 12.57 \\
\hline European Commission & 19007 & 66.9 & 58.1 & 69.7 & 8.51 \\
\hline United Nations & 2905 & 139.7 & 113.0 & 161.0 & 2.72 \\
\hline International Fund for Agric. & 735 & 180.3 & 153.7 & 203.6 & 0.89 \\
\hline Joint United Nations Program & 60 & 123.0 & 101.8 & 135.1 & 0.05 \\
\hline United Nations Childrens Fun & 563 & 221.3 & 142.2 & 282.0 & 0.83 \\
\hline United Nations Development P & 384 & 182.9 & 129.6 & 207.3 & 0.47 \\
\hline United Nations Economic Comm & 0.008 & 2.4 & 0.6 & 14.5 & 0.00 \\
\hline United Nations High Commissi & 203 & 78.2 & 63.1 & 113.2 & 0.11 \\
\hline United Nations Peacebuilding & 60 & 111.6 & 41.6 & 165.8 & 0.04 \\
\hline United Nations Population Fund & 267 & 125.0 & 102.8 & 142.0 & 0.22 \\
\hline United Nations Relief and Wo & 508 & 2.6 & 0.1 & 18.5 & 0.01 \\
\hline World Health Organization & 124 & 112.1 & 94.4 & 125.9 & 0.09 \\
\hline World Bank & 14255 & 194.1 & 177.7 & 203.2 & 18.52 \\
\hline International Monetary Fund & 1325 & 111.2 & 92.1 & 173.8 & 0.99 \\
\hline Regional development banks & 7561 & 125.0 & 115.1 & 138.7 & 6.33 \\
\hline African Development Bank & 20 & 78.6 & 50.6 & 128.1 & 0.01 \\
\hline African Development Fund & 2536 & 300.3 & 235.3 & 317.3 & 5.10 \\
\hline Asian Development Bank & 3293 & 30.7 & 9.5 & 100.6 & 0.68 \\
\hline Inter-American Development Bank & 1284 & 8.2 & 2.8 & 35.0 & 0.07 \\
\hline Islamic Development Bank & 428 & 164.6 & 141.5 & 186.4 & 0.47 \\
\hline Other Multilaterals (excl. Vertical Funds) & 2243 & 62.2 & 56.2 & 67.5 & 0.93 \\
\hline Arab Bank for Economic Devel & 194 & 270.7 & 198.1 & 293.3 & 0.35 \\
\hline Arab Fund for Economic Soci & 1318 & 7.2 & 2.3 & 27.5 & 0.06 \\
\hline Global Green Growth Institute & 5 & 177.3 & 102.9 & 228.6 & 0.01 \\
\hline Nordic Development Fund & 30 & 271.6 & 161.5 & 387.5 & 0.06 \\
\hline OPEC Fund for International & 637 & 106.4 & 95.2 & 118.6 & 0.45 \\
\hline Organization for Security an & 57 & 8.5 & 0.6 & 26.5 & 0.00 \\
\hline Non-governmental organizations (NGOs) & 6893 & 133.4 & 102.7 & 157.0 & 6.15 \\
\hline Action Aid & 119 & 168.8 & 125.0 & 204.4 & 0.13 \\
\hline Adra & 560 & 181.6 & 131.5 & 198.0 & 0.68 \\
\hline
\end{tabular}




\begin{tabular}{|c|c|c|c|c|c|}
\hline Broederlijkdelen & 8 & 140.6 & 61.3 & 213.9 & 0.01 \\
\hline Brot für die Welt & 40 & 94.9 & 82.9 & 107.8 & 0.03 \\
\hline Cafod & 42 & 91.7 & 81.8 & 114.7 & 0.03 \\
\hline Care & 779 & 161.0 & 143.8 & 174.7 & 0.84 \\
\hline Caritas Switzerland & 48 & 121.5 & 90.9 & 169.4 & 0.04 \\
\hline CCF & 184 & 124.6 & 97.1 & 146.9 & 0.15 \\
\hline Christian Aid & 22 & 105.9 & 81.5 & 193.3 & 0.02 \\
\hline Church of Sweden & 39 & 70.8 & 61.6 & 95.6 & 0.02 \\
\hline Concern & 116 & 194.9 & 128.4 & 227.2 & 0.15 \\
\hline Cord Aid & 153 & 97.9 & 64.0 & 122.1 & 0.10 \\
\hline Devp Canada & 21 & 76.2 & 4.0 & 118.8 & 0.01 \\
\hline Diakona & 15 & 77.1 & 63.7 & 105.0 & 0.01 \\
\hline EED & 93 & 99.9 & 74.3 & 142.0 & 0.06 \\
\hline FES & 53 & 41.6 & 31.2 & 68.3 & 0.01 \\
\hline Ford Foundation & 120 & 82.3 & 59.2 & 108.5 & 0.07 \\
\hline Goal & 77 & 279.5 & 149.3 & 309.4 & 0.14 \\
\hline Handicap International & 68 & 151.3 & 100.0 & 204.2 & 0.07 \\
\hline Helvetas & 8 & 154.6 & 110.5 & 169.4 & 0.01 \\
\hline Hivos & 48 & 74.9 & 57.9 & 106.2 & 0.02 \\
\hline ICCO & 97 & 100.1 & 81.9 & 112.7 & 0.07 \\
\hline ICRC & 743 & 92.2 & 24.7 & 184.9 & 0.46 \\
\hline IPPF & 27 & 139.1 & 107.4 & 171.9 & 0.02 \\
\hline Kellog & 124 & 24.7 & 16.5 & 59.9 & 0.02 \\
\hline Kinder not Hilfe & 52 & 115.1 & 86.6 & 145.3 & 0.04 \\
\hline Konrad Adenauer Stiftung & 44 & 23.6 & 10.3 & 40.7 & 0.01 \\
\hline KOO & 72 & 97.2 & 85.6 & 110.8 & 0.05 \\
\hline Marie Stopes International & 14 & 215.2 & 157.3 & 361.5 & 0.02 \\
\hline Mcarthur & 32 & 30.8 & 25.1 & 44.1 & 0.01 \\
\hline Mercy Corps & 23 & 23.0 & 10.5 & 112.8 & 0.00 \\
\hline Misereor & 142 & 62.2 & 53.6 & 82.7 & 0.06 \\
\hline MSF & 729 & 204.2 & 76.5 & 325.7 & 1.00 \\
\hline Norwegian Church Aid & 80 & 124.9 & 76.1 & 134.5 & 0.07 \\
\hline Norwegian Peoples Aid & 87 & 77.4 & 62.2 & 102.5 & 0.05 \\
\hline Novib & 54 & 165.2 & 114.1 & 219.4 & 0.06 \\
\hline Oxfam & 140 & 37.3 & 28.3 & 48.4 & 0.04 \\
\hline Plan International & 43 & 81.3 & 58.3 & 121.5 & 0.02 \\
\hline PSI & 10 & 108.0 & 82.6 & 129.6 & 0.01 \\
\hline Rockefeller & 229 & 168.8 & 141.6 & 207.0 & 0.26 \\
\hline SNV & 80 & 160.2 & 120.0 & 209.3 & 0.09 \\
\hline Soros & 146 & 205.0 & 135.8 & 254.0 & 0.20 \\
\hline STC & 115 & 137.2 & 105.9 & 176.9 & 0.11 \\
\hline Swiss Aid & 26 & 48.1 & 31.8 & 113.8 & 0.01 \\
\hline Swiss Contact & 22 & 98.4 & 68.2 & 119.0 & 0.01 \\
\hline TDHCH & 43 & 60.0 & 50.0 & 72.5 & 0.02 \\
\hline TDHNL & 14 & 37.8 & 23.1 & 113.1 & 0.00 \\
\hline Trocaire & 59 & 154.0 & 112.2 & 182.6 & 0.06 \\
\hline Vredeseilanden & 10 & 150.6 & 59.6 & 260.6 & 0.01 \\
\hline VSO UK & 364 & 114.7 & 92.3 & 145.6 & 0.28 \\
\hline Water Aid & 53 & 118.5 & 94.8 & 128.4 & 0.04 \\
\hline Welt Hunger Hilfe & 127 & 271.6 & 93.1 & 430.6 & 0.23 \\
\hline Woordendaad & 22 & 81.3 & 61.5 & 131.4 & 0.01 \\
\hline World Vision & 456 & 78.9 & 65.8 & 91.9 & 0.24 \\
\hline New aid & 27110 & 80.5 & 74.7 & 87.0 & 14.62 \\
\hline Non-DAC bilateral donors & 21382 & 63.5 & 55.0 & 73.8 & 9.09 \\
\hline Brazil & 146 & 285.7 & 138.7 & 415.2 & 0.28 \\
\hline Bulgaria & 0.2 & 3.0 & 0.3 & 48.6 & 0.00 \\
\hline Chile & 2 & 20.5 & 14.8 & 37.2 & 0.00 \\
\hline China & 7006 & 153.0 & 128.3 & 183.3 & 7.17 \\
\hline Colombia & 9 & 2.2 & 0.0 & 99.2 & 0.00 \\
\hline Croatia & 1 & 0.009 & 0.0005 & 16.2 & 0.00 \\
\hline Czech Republic & 43 & 59.9 & 39.8 & 71.1 & 0.02 \\
\hline Estonia & 13 & 14.0 & 7.4 & 29.8 & 0.00 \\
\hline Hungary & 8 & 5.1 & 1.9 & 16.1 & 0.00 \\
\hline Iceland & 14 & 347.8 & 207.2 & 450.0 & 0.03 \\
\hline India & 981 & 46.9 & 33.1 & 63.8 & 0.31 \\
\hline Israel & 108 & 52.0 & 26.9 & 59.3 & 0.04 \\
\hline Kazakhstan & 1 & 0.9 & 0.2 & 12.6 & 0.00 \\
\hline Kuwait & 1389 & 44.5 & 35.9 & 51.2 & 0.41 \\
\hline
\end{tabular}




\begin{tabular}{|c|c|c|c|c|c|}
\hline Latvia & 1 & 9.9 & 3.4 & 36.5 & 0.00 \\
\hline Liechtenstein & 3 & 59.9 & 31.2 & 81.1 & 0.00 \\
\hline Lithuania & 2 & 1.7 & 0.7 & 12.6 & 0.00 \\
\hline Monaco & 5 & 272.1 & 198.0 & 334.5 & 0.01 \\
\hline Poland & 128 & 8.4 & 6.2 & 23.4 & 0.01 \\
\hline Qatar & 1741 & 2.2 & 0.4 & 19.7 & 0.03 \\
\hline Russia & 220 & 42.4 & 34.9 & 74.3 & 0.06 \\
\hline Saudi Arabia & 5109 & 10.4 & 4.2 & 30.1 & 0.36 \\
\hline Slovak Republic & 9 & 17.9 & 11.8 & 45.7 & 0.00 \\
\hline Slovenia & 11 & 18.1 & 9.1 & 23.6 & 0.00 \\
\hline South Africa & 36 & 209.4 & 76.3 & 367.0 & 0.05 \\
\hline Taiwan & 31 & 41.4 & 26.0 & 68.8 & 0.01 \\
\hline Thailand & 4 & 44.9 & 22.3 & 111.7 & 0.00 \\
\hline Turkey & 1559 & 11.1 & 6.6 & 44.0 & 0.12 \\
\hline United Arab Emirates & 2800 & 9.8 & 5.4 & 21.6 & 0.18 \\
\hline New global actors & 5729 & 144.1 & 134.6 & 162.1 & 5.53 \\
\hline \multicolumn{6}{|l|}{$\overline{\text { Global Alliance for Vaccines and }}$} \\
\hline Immunization & 1140 & 195.9 & 171.2 & 207.8 & 1.50 \\
\hline \multicolumn{6}{|c|}{ Global Fund to fight AIDS, Tuberculosis and } \\
\hline Malaria & 2934 & 141.3 & 126.5 & 171.6 & 2.78 \\
\hline Global Environment Facility & 959 & 73.2 & 61.4 & 80.8 & 0.47 \\
\hline Bill and Melinda Gates Foundation & 696 & 168.9 & 134.5 & 223.7 & 0.79 \\
\hline
\end{tabular}

Notes: All volumes in the first column, except the new financial flows, refer to aid; The average poverty reducing efficiency for all donors is set to 100; The upper and lower bounds are derived from the sensitivity analysis; Column 5 gives the proportion of total poverty reduction defined as poverty reduction efficiency per aid dollar multiplied by the total aid volume - achieved by each donor or donor group. 


\section{Appendix B: Calibration of the model}

This section elaborates on the calibration of the theoretical model. Specifically, we discuss the elasticity of poverty with respect to realized per-capita-income $(\alpha)$, the relationship between a country's policy and its saturation point $\left(\beta_{i}\right)$ and the fraction of the first aid-dollar that is not lost due to transaction costs $\left(\varepsilon_{i}\right)$. We establish the benchmark values (as well as values to use in the sensitivity analysis) of the parameters that are a part of the concerned functions and that will be used in the calibrations of our model, and describe necessary transformations of key indicators.

\section{B1. The elasticity of poverty with respect to realized per-capita-income, $\alpha$}

In the benchmark setup we assume and that the elasticity of poverty with respect to realized per capita income, denoted $\alpha$, is 1.5 . We base this figure on previous empirical literature in the area. In particular, Alvaredo and Gasparini (2015) estimate the average total growth elasticity of poverty (as measured by the proportion of individuals below $\$ 1.25$ a day) over the period 1981-2010 to be around 1.5. Based on a careful review of the literature, they note that most estimates of $\alpha$ lie in the range of 1-2 (See e.g. World Bank, 2000; Bourguignon, 2003; Ferreira and Ravallion, 2009; Ravallion, 2012). Collier and Dollar (2002), finally, use $\alpha=2.0$. Against this background, we use $\alpha=1.5$ as benchmark, and 1.0 respective 2.0 in the robustness analysis.

\section{B2. The saturation point for a country with average policy, $\beta_{0}$}

Just as the standard assumption of diminishing returns in the aid-growth literature, we assume a quadratic relationship between aid and realized income, i.e. that recipient country governments have limited absorptive capacity when it comes to delivering consumption just as in delivering economic growth. With large aid volumes, a recipient country will reach a point where they can no longer absorb or spend aid efficiently.

In our benchmark calibration, we assume that the saturation point for a country with average policy score, which we denote $\beta_{0}$, occurs when aid constitutes 25 percent of GDP. As noted in Section 3, we base this figure on the estimates in Clemens et al (2012), who find inflection points for the aid-growth relationship when aid exceeds about 20-25 percent of GDP. This would suggest a reasonable benchmark estimate of $\beta_{0}$ is 22.5 percent. Since we do not 
use the same aid measure as Clemens et al (2002), however, we need to transform their estimates to a saturation point that is relevant in our setup. To begin with, we use aid commitments rather than actual disbursements. Furthermore, unlike Clemens et al., we include aid from NGOs, non-DAC bilateral donors and 'New global actors'. While the latter two posts were negligible during their period under study (1970-2005), we need to adjust for the fact that they omitted aid from NGOs. Finally, we drop the part of reported aid that does not involve an actual transfer of money (e.g. administrative costs, see Section 4). Based on aid commitments being 20.8 percent higher than net aid disbursements, aid from NGOs being 5.9 percent of 'traditional aid', and the aid posts that we drop being 10.4 percent of (reported) aid, we conclude that a saturation point of 22.5 percent in Clemens et al. (2012) correspond to a saturation point of approximately 25 percent with our measure. ${ }^{18}$ To evaluate the sensitivity of results to using alternative saturation points, we use $\beta_{0}=20$ and $\beta_{0}=30$ percent in alternative calibrations.

B3 The saturation point $\beta_{i}$ and the fraction of the first aid-dollar that is not lost due to transaction costs, $\varepsilon_{i}$

As noted, we set the saturation point for a country with average policy, $\beta_{0}$, to 25 percent in our benchmark estimations. Like Collier and Dollar (2002), however, we also let country $i$ 's saturation point $\beta_{i}$ and the fraction of its first aid-dollar that is not lost to transaction costs, $\varepsilon_{i}$, vary with policy. Based on their theoretical model, we derive the functional form for this relationship, and based on their empirical results, we arrive at the parameter estimates to use in the benchmark and sensitivity analysis.

The saturation point, $\beta_{i}$, and the fraction of the first aid-dollar that is not lost due to transaction costs, $\varepsilon_{i}$, enter our theoretical model in equation (3). Below, we show how we derive this equation from Collier and Dollar (2002). In their setup:

$$
\frac{\partial G_{i}}{\partial A_{i}}=b_{3}+b_{5} P_{i}+2 b_{4} A_{i}
$$

where $P_{i}$ denotes Policy (below, we return to how this is measured) in country $i$. Based on average Policy, $\bar{P}$, and the standard deviation of Policy, $P_{s d}$, we construct the following variable transformation to define Normalized Policy in country $i, P_{N, i}$ :

\footnotetext{
$1822.5 \times 1.208 \times 1.059 \times 0.896=25.8$.
} 


$$
P_{N, i}=\frac{P_{i}-\bar{P}}{P_{s d}}
$$

Combining equation (B1) and (B2) we get:

$$
\frac{\partial G_{i}}{\partial A_{i}}=\left(b_{3}+b_{5} \bar{P}\right)\left(\left(1+\frac{b_{5} P_{s d}}{b_{3}+b_{5} \bar{P}} P_{N, i}\right)+\frac{2 b_{4}}{b_{3}+b_{5} \bar{P}} A_{i}\right)
$$

We now define the following variable transformations:

$$
\begin{aligned}
& P_{f}=\frac{b_{5} P_{s d}}{b_{3}+b_{5} \bar{P}} \\
& \eta=-\frac{b_{3}+b_{5} \bar{P}}{2 b_{4}}
\end{aligned}
$$

$P_{f}$ refers to a 'Policy Factor'. Based on equations (B3) - (B5) we can write:

$$
\frac{\partial G_{i}}{\partial A_{i}}=\left(b_{3}+b_{5} \bar{P}\right)\left(1+P_{f} P_{N, i}\right)\left(1-\frac{A_{i}}{\left(1+P_{f} P_{N, i}\right) \eta}\right)
$$

From equation (B6) we see that the saturation point is $\left(1+P_{f} P_{N, i}\right) \eta$. This implies that for a country with average policy $\left(P_{N, i}=0\right)$, the saturation point is given by $\eta$. We already have a value for the saturation point for a country with average policy - that is, $\beta_{0}$ - and can thus replace $\eta$ with $\beta_{0}$ in equation (B6).

We assume that policy has the same effect on $q_{i}$ (the relationship between aid and realized per capita income) as on growth. The magnitude of $\frac{\partial q_{i}}{\partial A_{i}}$ will, however, not be the same as the magnitude of $\frac{\partial G_{i}}{\partial A_{i}}$, since $q_{i}$ and $G_{i}$ are measured in different units. In terms of magnitude, we must ensure that $\frac{\partial q_{i}}{\partial A_{i}} \leq 1$, so that one aid dollar never adds to realized income by more than one dollar. We therefore let $\frac{\partial q_{i}}{\partial A_{i}}$ have the form as $\frac{\partial G_{i}}{\partial A_{i}}$, but multiply it with a factor so that $\frac{\partial q_{i}}{\partial A_{i}}=1$ when aid is zero and $P_{N, i}=P_{N, \max }$. This gives us:

$$
\frac{\partial q_{i}}{\partial A_{i}}=\frac{1}{\left(b_{3}+b_{5} \bar{P}\right)\left(1+P_{f} P_{N, \max }\right)} \frac{d G_{i}}{d A_{i}}
$$

Combining equations (B6) and (B7), and replacing $\eta$ by $\beta_{0}$, we get:

$$
\frac{\partial q_{i}}{\partial A_{i}}=\frac{1+P_{f} P_{N, i}}{1+P_{f} P_{N, \max }}\left(1-\frac{A_{i}}{\left(1+P_{f} P_{N, i}\right) \beta_{0}}\right)
$$

Letting:

$$
\epsilon_{i}=\frac{1+P_{f} P_{N, i}}{1+P_{f} P_{N, \max }}
$$


and:

$$
\beta_{i}=\left(1+P_{f} P_{N, i}\right) \beta_{0}
$$

we arrive at:

$$
\frac{\partial q_{i}}{\partial A_{i}}=\epsilon_{i}\left(1-\frac{A_{i}}{\beta_{i}}\right)
$$

Equation (B11) together with $q_{i}=1$ when $A_{i}=0$ implies that $q_{i}=1+\epsilon_{i}\left(A_{i}-\frac{A_{i}{ }^{2}}{2 \beta_{i}}\right)$, which is Equation (3) in our theoretical model. So far, we have shown how to calibrate $\epsilon_{i}$ and $\beta_{i}$ based on Collier and Dollar (2002). We use equations (B2), (B4), (B9) and (B10) for the calibration.

Our benchmark estimate of $P_{f}$ is based on the empirical results of Collier and Dollar (2002). Specifically, we used use their coefficient estimates for $b_{3}$ and $b_{5}$, as well as their measures of average Policy, $\bar{P}$, and the standard deviation of Policy, $P_{s d} \cdot{ }^{19}$ Plugging in $b_{3}=$ $-0.54, b_{5}=0.31, \bar{P}=3.04$ and $P_{s d}=0.875$ in equation (B4) we get our benchmark $P_{f}=$ 0.67 .

To get estimates of $P_{f}$ for the sensitivity analysis, we follow the approach in Collier and Dollar (2002, p. 1481), changing their estimated coefficients of $b_{3}$ and $b_{5}$ by one standard deviation:

Lower bound: $b 3+s . d .(0.39) ; b 5-s . d .(0.11)$

Higher bound: $b 3-s . d .(0.39) ; b 5+s . d .(0.11)$

Doing so, we get $P_{f}=0.38$ as lower bound and $P_{f}=1.06$ as higher bound for the sensitivity analysis.

We calculate $P_{N, i}$ and $P_{N, \max }$ using equation (B2), where $P_{i}$ and $P_{\max }$ refer to actual values in the policy index we are using (ACPR in the benchmark setup, CPR in the sensitivity analysis). $\bar{P}$ and $P_{s d}$ are transformations of the values used in the Collier and Dollar (2002) study, $\left(\bar{P}=3.04\right.$ and $\left.P_{s d}=0.875\right)$ into the index we are using. We elaborate on these transformations in the next section. Finally, given $P_{N, i}, P_{N, \max }$, and $P_{f}$ (and $\beta_{0}$ from Clemens et al., 2012), we calculate $\epsilon_{i}$ and $\beta_{i}$ using equations (B9) and (B10).

\footnotetext{
${ }^{19} b_{3}=-0.54$ and $b_{5}=0.31$ are found in Column 1 in their Table 1 on page $1479, \bar{P}=3.04$ is found on page 1482 , and $P_{s d}=0.875$ is from Table 2 on page 1481 .
} 


\section{B4 Adjusting for the use of different policy indicators}

To calculate Normalized Policy, $P_{N, i}$, we compare the policy score for each country in our dataset to the average and the standard deviation of the policy score in the dataset of Collier and Dollar (2002). Doing so, however, we need to adjust for the fact that we use different policy indicators. In particular, to integrate structural economic vulnerability and low human capital into the allocation rule, we use the ACPR in our benchmark calibration (and CPR in the sensitivity analysis). Collier and Dollar (2002), on the other hand, used the unweighted average of the components in the World Bank's Country Policy and Institutional Assessment (CPIA) measure. This contrasts with both the CPR, which is a weighted average of the components in CPIA, and the ACPR, which is an index made up of CPR together with measures of vulnerability. We thus need to transform the average and standard deviation $(\bar{P}=3.04$ and $\left.P_{s d}=0.875\right)$ from the Collier and Dollar (2002) policy index into the scale of the ACPR and CPR, respectively. ${ }^{20}$ We carry out this transformation in two steps:

In a first step, we account for the fact that before 1998 the CPIA was measured on a scale from 1-5 and after that on a scale from 1-6 (Gonzalez and Nishiuchi, 2018). With the new scale, both average and median CPIA scores increased from 3.0 in the 1977-1997 period to 3.5 in the 1998-2016 period (Gonzalez and Nishiuchi, 2018). Against this background, we make a linear transformation:

$$
\frac{\left(P_{i}^{\text {New }}-1\right)}{6-1}=\frac{\left(P_{i}^{\text {old }}-1\right)}{5-1} \Rightarrow P_{i}^{\text {New }}=1.25 P_{i}^{\text {old }}-0.25
$$

where $P_{i}^{\text {Old }}$ refers the policy measure used by Collier and Dollar (2002), and $P_{i}^{\text {New }}$ refers to $P_{i}^{\text {Old }}$ transformed into the 1-6 points scale. From this, we find that:

$$
\begin{aligned}
& \bar{P}^{\text {New }}=1.25 \bar{P}^{\text {old }}-0.25=3.5500 \\
& P_{s d}^{N e w}=1.25 P_{s d}^{\text {Old }}=1.0938
\end{aligned}
$$

In a second step, we transform $\bar{P}^{\text {New }}$ and $P_{s d}^{N e w}$ into the scale of the ACPR and the CPR, respectively. Here we need to introduce some new notations. $A C P R_{i}$ and $C P R_{i}$ refer to our respective policy measures. $P_{i}^{\text {New,09-13 }}$ refers to a policy measure constructed as the one used in Collier and Dollar (2002), but for our 2009-2013 dataset. Finally, $P_{i}^{A C P R}$ and $P_{i}^{C P R}$ refer to

\footnotetext{
${ }^{20}$ Please note that the result of this transformation will not be the same as the average and standard deviation of ACPR (respective CPR) in our 2009-2013 dataset.
} 
the transformed versions of the Collier and Dollar (2002) Policy Index. All these indicators $A C P R_{i}, C P R_{i}, P_{i}^{N e w, 09-13}, P_{i}^{A C P R}$ and $P_{i}^{C P R}-$ are measured on a 1-6 points scale.

In order to transform $\bar{P}^{N e w}$ into $\bar{P}^{A C P R}$ (and correspondingly, $P_{s d}^{N e w}$ into $P_{s d}^{A C P R}$ ) we multiply $\bar{P}^{\text {New }}$ by the scaling factor $\frac{\overline{A C P R}}{\bar{P}^{N e w, 09-13}}$. Doing the same for the average and standard deviation of $C P R$ we thus calculate:

$$
\begin{aligned}
& \bar{P}^{A C P R}=\frac{\overline{A C P R}}{\bar{P}^{N e w, 09-13}} \bar{P}^{N e w}=\frac{3.1438}{3.3062} 3.5500=3.38 \\
& P_{s d}^{A C P R}=\frac{A C P R_{s d}}{P_{s d}^{N e w, 09-13}} P_{s d}^{N e w}=\frac{0.2605}{0.4852} 1.0938=0.59 \\
& \bar{P}^{C P R}=\frac{\overline{C P R}}{\bar{P}^{N e w, 09-13}} \bar{P}^{N e w}=\frac{3.1662}{3.3062} 3.5500=3.40 \\
& P_{s d}^{C P R}=\frac{C P R_{s d}}{P_{s d}^{\text {New, } 09-13}} P_{s d}^{N e w}=\frac{0.4512}{0.4852} 1.0938=1.02
\end{aligned}
$$

Based on these, we calculate the maximum policy values in our dataset (note that it is pure coincidence that $A C P R_{N, \max }$ and $C P R_{N, \max }$ happen to get the same numerical value):

$$
\begin{aligned}
& A C P R_{\text {Max }}=5.10 \\
& C P R_{\text {Max }}=5.10
\end{aligned}
$$

Finally, we combine equation (B2) with equations (B15) - (B20) to get the normalized policy indicators we are using in our calibrations:

$$
\begin{aligned}
& A C P R_{N, i}=\frac{A C P R_{i}-\bar{P}^{A C P R}}{P_{s d}^{A C P R}}=\frac{A C P R_{i}-3.38}{0.59} \\
& C P R_{N, i}=\frac{C P R_{i}-\bar{P}^{C P R}}{P_{s d}^{C P R}}=\frac{C P R_{i}-3.40}{1.02} \\
& A C P R_{N, \text { max }}=\frac{A C P R_{\max }-\bar{P}^{A C P R}}{P_{s d}^{A C P R}}=\frac{5.10-3.38}{0.59}=2.92 \\
& C P R_{N, \max }=\frac{C P R_{\max }-\bar{P} C P R}{P_{s d}^{C P R}}=\frac{5.10-3.40}{1.02}=1.67
\end{aligned}
$$




\section{References}

AidData (2014a) "Saudi Arabia TUFF Donor Dataset, Version 1.0", available at: https://www.aiddata.org/data/saudi-arabia-tuff-donor-dataset-level-1-v1-0

AidData (2014b) "Qatar TUFF Donor Dataset, Version 1.0", available at: https://www.aiddata.org/data/qatar-tuff-donor-dataset-level-1-v1-0

AidData (2017a) "AidDataCore_ResearchRelease_Level1_v3.0 Research Releases dataset", Williamsburg, VA : AidData, available at: https://www.aiddata.org/data/aiddata-coreresearch-release-level-1-v3-0

AidData (2017b) "Global Chinese Official Finance Dataset, Version 1.0". available at: http://aiddata.org/data/chinese-global-official-finance-dataset.

Alvaredo, F. and L. Gasparini (2015) "Recent trends in inequality and poverty in developing countries", in Handbook of income distribution, Volume 2, 2015, Pages 697-805, Elsevier, Edited by Edited by A. B. Atkinson and F. Bourguignon

Bourguignon, F. (2003) “The growth elasticity of poverty reduction: Explaining heterogeneity across countries and time periods", in Eichler and Turnovsky (eds). Inequality and Growth: Theory and Policy Implications. CESifo Seminar Series, London: MIT Press.

Ferreira, F. and Ravallion, M. (2009). Poverty and inequality: The global context. In Salverda, Nolan and Smeeding (eds). The Oxford Handbook of Economic Inequality. Oxford: Oxford University Press.

Gonzalez, Christian Yves and Toru Nishiuchi (2018) "Revisiting the relevance of the World Bank's Country policy and institutional assessment (CPIA) on growth”, Discussion paper, MTI Global practice, no 9, December 2018, the World Bank Group.

Guillaumont, P., S. Guillaumont Jenneney and L. Wagner (2017a) "How to take into account vulnerability in aid allocation criteria and lack of human capital as well: improving the performance based allocation", World Development, vol 90. pp. 27-40.

IDA (2017a) “Country Policy and Institutional Assessment”. Downloaded 171004. Available at: https://datacatalog.worldbank.org/dataset/country-policy-and-institutional-assessment

IDA (2017b) "IDA Country Performance Ratings (CPR) Historical series: CPR 2006-2012. CPR 2013 and 2014", World Bank Group, Downloaded 171005. available at: http://ida.worldbank.org/financing/resource-management/ida-country-performanceratings 
International Committee of the Red Cross (2014) "ICRC Annual Report 2013”, Geneva, Switzerland.

International Committee of the Red Cross (2013) "ICRC Annual Report 2012", Geneva, Switzerland.

International Committee of the Red Cross (2012) "ICRC Annual Report 2011", Geneva, Switzerland.

International Committee of the Red Cross (2011) "ICRC Annual Report 2010", Geneva, Switzerland.

International Committee of the Red Cross (2010) "ICRC Annual Report 2009", Geneva, Switzerland.

Koch, Dirk-Jan; Axel Dreher; Rainer Thiele and Peter Nunnenkamp (2009) "Keeping a Low Profile: What Determines the Allocation of Aid by Non-Governmental Organizations?" World Development, 37(5), pp. 902-918.

Médecins Sans Frontières (2014) “International Financial Report 2013”, Geneva, MSF International.

Médecins Sans Frontières (2013) “International Financial Report 2012”, Geneva, MSF International.

Médecins Sans Frontières (2012) “International Financial Report 2011”, Geneva, MSF International.

Médecins Sans Frontières (2011) “International Financial Report 2010”, Geneva, MSF International.

Médecins Sans Frontières (2010) “International Financial Report 2009”, Geneva, MSF International.

OECD-DAC (2020) "Aid (ODA) disbursements to countries and regions [DAC2a]", TABLE2A_30072020074834372.csv Downloaded 200730. Available at: https://stats.oecd.org/Index.aspx?DataSetCode=Table2A

Ravallion, M. and S. Chen (1997) "What can new survey data tell us about recent changes in distribution and poverty?", World Bank Economic Review, 11 (2), 357-382

Ravallion, M. (2012) "Why don't we see poverty convergence?”, American Economic Review $102(1)$.

United Nations (2019a) "LDC data", Department of Economic and Social Affairs Economic Analysis, available at: https://www.un.org/development/desa/dpad/least-developedcountry-category/ldc-data-retrieval.html 
UNDP (2016) "Human Development Index (HDI)". Downloaded 161222. Available at: http://hdr.undp.org/en/content/human-development-index-hdi

World Bank (2000) "World Development Report: Attacking Poverty”, New York: Oxford University Press.

World Bank (2019b) "World Development Indicators", available at: https://datacatalog.worldbank.org/dataset/world-development-indicators.

World Bank (2019c) "Worldwide Governance Indicators", available at https://datacatalog.worldbank.org/dataset/worldwide-governanceindicators/resource/d048db01-0a66-485b-96a3-db28287b7a65 